\title{
Lessons the United States Can Learn From Other Countries' Territorial Systems For Taxing Income of Multinational Corporations
}

\section{Citation}

Rosanne Altshuler, Shephen Shay, \& Eric Toder, Lessons the United States Can Learn From Other Countries' Territorial Systems For Taxing Income of Multinational Corporations (Urban Institute \& Brookings Institution Tax Policy Center, Jan. 21, 2015).

\section{Published Version}

http://www.taxpolicycenter.org/UploadedPDF/2000077-lessons-the-us-can-learn-from-othercountries.pdf

\section{Permanent link}

http://nrs.harvard.edu/urn-3:HUL.InstRepos:13839265

\section{Terms of Use}

This article was downloaded from Harvard University's DASH repository, and is made available under the terms and conditions applicable to Other Posted Material, as set forth at http:// nrs.harvard.edu/urn-3:HUL.InstRepos:dash.current.terms-of-use\#LAA

\section{Share Your Story}

The Harvard community has made this article openly available.

Please share how this access benefits you. Submit a story.

Accessibility 


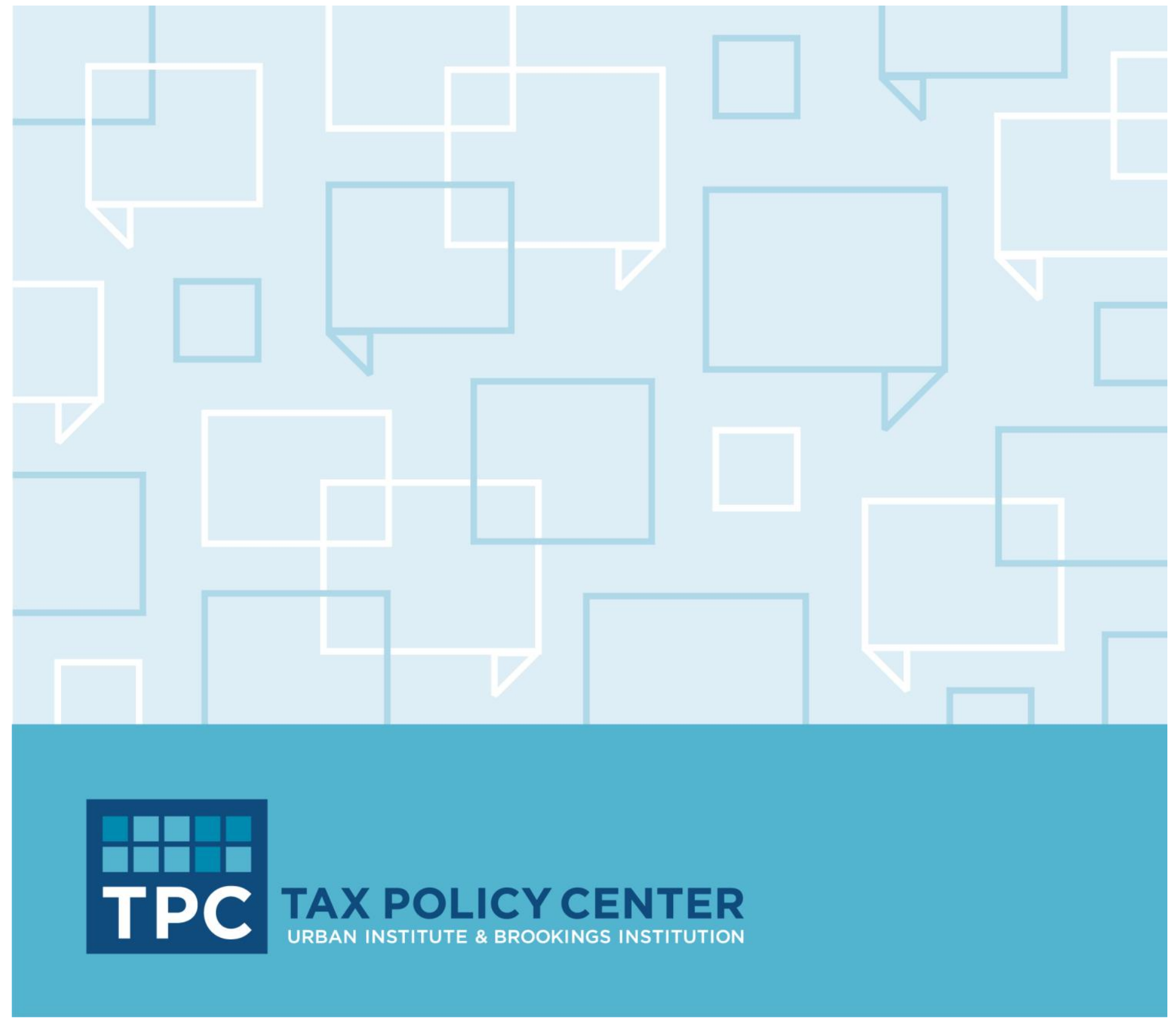

LESSONS THE UNITED STATES CAN LEARN FROM OTHER COUNTRIES' TERRITORIAL SYSTEMS FOR TAXING INCOME OF MULTINATIONAL CORPORATIONS

Rosanne Altshuler, Stephen Shay, and Eric Toder January 21, 2015 


\section{ACKNOWLEDGEMENTS}

This report was prepared under an Urban Institute grant with the Smith Richardson Foundation, grant \# 2013-9319.

Altshuler is a professor of economics at Rutgers University. Shay is a professor of practice at Harvard Law School. Toder is an Institute fellow at the Urban Institute and codirector of the Tax Policy Center. The authors benefited from insights supplied at a conference titled "What the United States Can Learn from Other Countries' Territorial Tax Systems," which was held at the Urban Institute on February 28, 2014. The authors thank the conference participants for information and perspectives they supplied in the conference discussion and in private conversations and correspondence afterward. The authors also thank Amanda Eng for excellent research assistance and Brian Arnold, Alan Auerbach, Hugh Ault, Kim Clausing, Steven Edge, Ross Fallone, Joni Geuther, Harry Grubert, Peter Merrill, Manabu Nakamori, Erik Roeder, Matthew Ryan, and Richard Vann for helpful comments on an earlier draft of the report. All remaining errors are the responsibility of the authors.

The findings and conclusions contained within are those of the author and do not necessarily reflect positions or polices of the Tax Policy Center or its funders. 
The United States has a worldwide system that taxes the dividends its resident multinational corporations receive from their foreign affiliates, while most other countries have territorial systems that exempt these dividends. This report examines the experience of four countries - two with long-standing territorial systems and two that have recently eliminated taxation of repatriated dividends. We find that the reasons for maintaining or introducing dividend exemption systems varied greatly among them and do not necessarily apply to the United States. Moreover, classification of tax systems as worldwide or territorial does not adequately capture differences in how countries tax foreign-source income. 


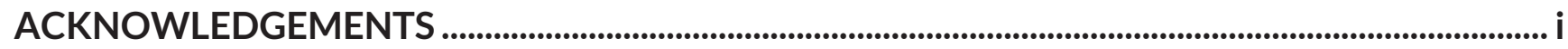

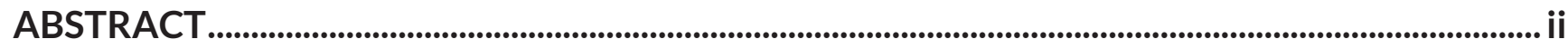

INTRODUCTION

ECONOMIC AND FISCAL CHARACTERISTICS OF THE UNITED STATES, AUSTRALIA, GERMANY, JAPAN, AND THE UNITED KINGDOM ......................................................................

Size of Economy and Importance of Trade and Capital Flows............................................................................

Differences in Business Sector and Industry Characteristics...........................................................................5

General Tax Structures and Fiscal Position ..............................................................................................................

Rules for Taxing Business Income ..........................................................................................................................

HOW THE CURRENT US TAX SYSTEM WORKS ..................................................................................... 10

The Building Blocks of the US International Tax System ...................................................................................11

What Foreign-Source Income Is Subject to US Tax and When? .....................................................................11

How the United States Prevents Double Taxation........................................................................................ 15

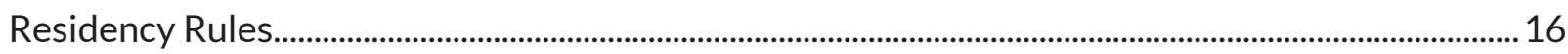

Does the United States Collect Corporate Tax Revenue from the Foreign Profits of US Firms? ........ 17

How Would MNC Behavior Change if the United States Enacted a Dividend Exemption System?...17

CASE STUDIES OF TERRITORIAL TAX SYSTEMS IN THE UNITED KINGDOM, JAPAN,

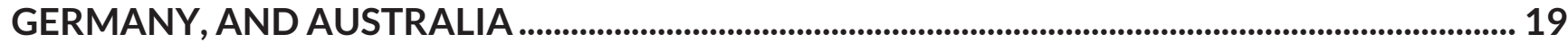

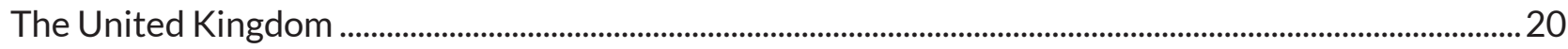

Background: UK Corporate Taxation before 2000 ..................................................................................2 20

Drivers of Change: EU Law Constraints and Inter-country Tax Competition..........................................21

UK Corporate Taxation Today ..................................................................................................................... 22

Summary: Reduced Taxation of Foreign Business Income .......................................................................2

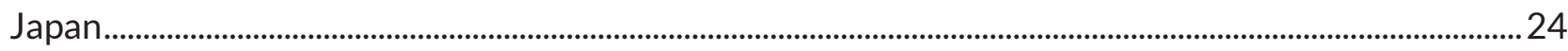

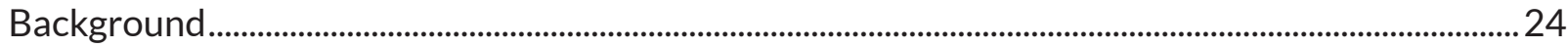

Drivers of Change: Economic Stagnation, High Corporate Tax Rates, and Unrepatriated Offshore

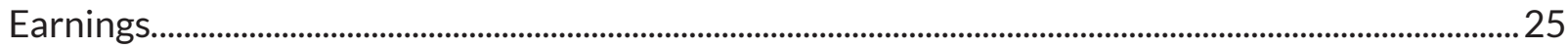

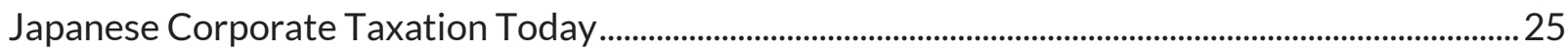

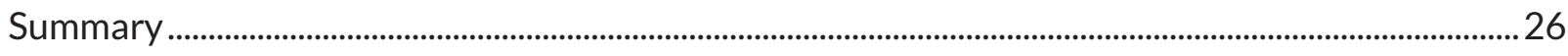

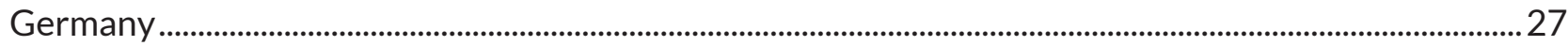

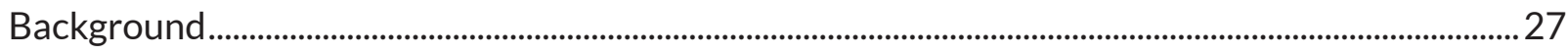

German Corporate Taxation Today .............................................................................................................. 28

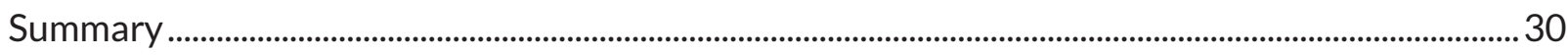

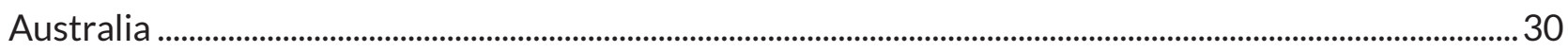

Background...................................................................................................................................................

Australian Corporate Taxation Today.............................................................................................................. 31

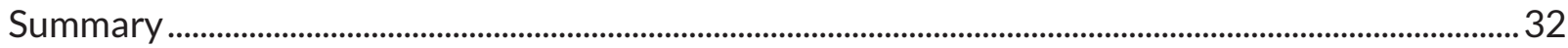

CONCLUSIONS .......................................................................................................................... 33

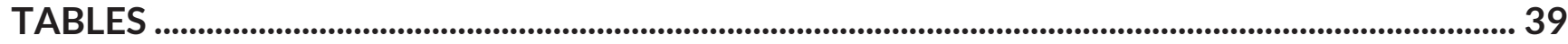

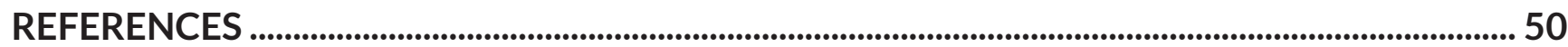


The United States is one of few remaining countries with a tax on the worldwide income of its resident multinational corporations (MNCs). Most of the country's major trading partners instead have some form of territorial system that exempts most active foreign-source income of their resident MNCs. Within the past five years, both the United Kingdom and Japan have enacted territorial systems by exempting either all or 95 percent of the dividends that their resident MNCs receive from their foreign affiliates.

In practice, the difference in corporate tax policy between the United States and its trading partners is nowhere near as stark as the labels "worldwide" and "territorial" suggest. All tax systems are hybrid systems that tax at reduced effective rates some foreign business income. The United States allows its MNCs to defer tax on most income of foreign subsidiaries until that income is repatriated as a dividend to the US parent company and allows a liberal credit for foreign income taxes paid. As a result, the United States collects little tax on the dividends its MNCs receive from their foreign affiliates. And most countries that exempt dividends from foreign affiliates impose tax on some foreign-source income as it is accrued to protect their domestic corporate tax base. Because of the electivity of operating through a foreign branch, the deferral of tax on most income accrued within a foreign subsidiary, and the generosity of the foreign tax credit limitation, the United States also does not collect much tax on foreign income earned from operating directly in another country. In any assessment of international tax policy, as in so much else in taxation, the devil is in the details.

Nonetheless, the taxation of foreign subsidiary dividends and, in some cases, income earned in foreign operating branches represents a significant difference in international tax policy between the United States and most other countries. And many in the United States are calling for a move to a territorial tax system that exempts foreign dividends from active business income, although proposals introduced in Congress to date also have been accompanied by expanded measures to protect the US corporate tax base.1

This report explores the lessons that the United States can learn from other countries' experiences with territorial tax systems. We examine the approaches and experience of four other countries-two with long-standing territorial systems (Germany and Australia) and two that in recent years eliminated taxation of the dividends their MNCs receive from foreign affiliates (the United Kingdom and Japan). We compare the economies and fiscal systems of the four countries and the United States, commenting on how differences between them may affect tax policy choices. We then discuss the building blocks that make up any international tax regime, summarize the choices the United States has made and the effects those choices may have on corporate behavior, describe the international tax rules of the four other countries, and compare

1 The major congressional proposals are the tax reform proposal introduced in the House by Representative Dave Camp (Committee on Ways and Means 2014) and the international tax reform proposals by Senator Max Baucus (Committee on Finance 2013). 
those rules with the rules of the United States. We examine factors that have driven the policy choices in each of the four comparison countries and the lessons the United States can take away from their experiences.

Participants at an invitation-only conference at the Urban Institute on February 28, 2014, greatly assisted the development of our thinking on these issues and our knowledge of other countries' experiences. The participants included academic experts, practitioners, and public officials from the United States and the countries examined in this report. These individuals generously shared their information, insights, and perspectives. A summary of the conference discussion can be found in Toder (2014). 


\section{SIZE OF ECONOMY AND IMPORTANCE OF TRADE AND CAPITAL FLOWS}

Compared with the other countries examined in this report, the United States has the largest economy by far (table 1) and, except for Japan, the one least exposed to international trade. The gross domestic product (GDP) of the United States is over 40 percent larger than the sum of the GDPs of Australia, Germany, Japan, and the United Kingdom, primarily because the United States has a much larger population than the comparison countries. The United States in 2012 also had the largest GDP per capita, about US $\$ 52,000$, compared with US $\$ 45,000$ for Australia, US $\$ 42,000$ for Germany, and US\$35,000 for Japan and the United Kingdom.

Exports and imports of goods and services accounted for a much smaller share of GDP in the United States than in Australia, Germany, and the United Kingdom and about the same share as in Japan. Exports accounted for only 13 percent of GDP in the United States, compared with 52 percent in Germany, 32 percent in the United Kingdom, 20 percent in Australia, and 15 percent in Japan. Imports accounted for 16 percent of GDP in the United States, compared with 46 percent in Germany, 34 percent in the United Kingdom, 21 percent in Australia, and 16 percent in Japan.

International investment positions, measured as stocks of direct and portfolio investments, differ substantially among the five countries (table 2). Japan is a capital-exporting country with net outbound foreign direct investment (FDI) amounting to 15 percent of GDP and net outbound portfolio investment amounting to 46 percent of GDP, whereas Australia is a capital-importing country with net inbound FDI of 12 percent of GDP and net inbound portfolio investment of 51 percent of GDP. Germany, the United States, and the United Kingdom are all net exporters of FDI but net importers of portfolio capital. ${ }^{2}$

The net figures, however, result from very different volumes of gross capital outflows and inflows as a share of GDP. The United Kingdom has the largest volume of both inbound and outbound FDI and portfolio investment, although the net balances of each are small. So the United Kingdom is very much exposed to international capital movements despite its small net position. Japan has the smallest gross flows of FDI as a share of GDP, although among the five countries, it is the largest net exporter (as a share of GDP) of both FDI and portfolio investment because of its very high rate of private saving. Australia has the second-largest gross inflows of both FDI and portfolio investment as a percentage of GDP (below the United Kingdom) and the largest net inflow of both types of investment.

2 Because the figures in table 2 on FDI and portfolio investment come from different sources, we have not combined them in the table or referred to their sum in the text. 
Ratios of capital positions to GDP vary from year to year, in response to changes in economic conditions and, for some countries, changes in tax and other policies (tables 2a and 2b). In 2010, as in 2012, Japan was a net capital-exporting country; Australia was a net capital-importing country; and Germany, the United States, and the United Kingdom were all net exporters of FDI but net importers of portfolio capital (table 2b). As in 2012, the United Kingdom in 2010 had the largest gross volume of both FDI and portfolio investment as a share of GDP among the five countries, and Australia had the second-largest gross inflows of both FDI and portfolio investment. Japan in 2010, as in 2012, had the smallest gross flows of FDI as a share of GDP.

At the beginning of the 21st century, however, the picture was somewhat different (table 2c). In 2000 (2001 for portfolio capital), the United Kingdom still had the largest shares of gross capital flows, both inbound and outbound and for both portfolio investments and FDI. The United Kingdom also had the largest net outflows of both portfolio investments and FDI. The United States, Germany, and Japan also had positive net outflows of FDI, and Australia had a net inflow of FDI, but the net flows were 5 percent of GDP or less for all four countries and less than 1 percent of GDP for the United States and Germany. As in 2012, Japan had net outflows of portfolio capital and Australia, Germany, and the United States had net inflows. The United Kingdom, however, went from substantial net outflows of portfolio capital at the beginning of the century to net inflows by 2012 .

Between 2000 for FDI (2001 for portfolio investment) and 2012, gross inflows and outflows of both FDI and portfolio investments as shares of GDP increased in all five countries, although by varying amounts. The United Kingdom experienced the largest growth in inbound FDI and inbound portfolio investments as shares of GDP, and Australia experienced significant growth in inbound portfolio investments and more modest growth in inbound FDI. Japan, Germany, and the United States experienced very modest growth in inbound FDI but somewhat larger growth in inbound portfolio investments. Outbound FDI increased the most in the United States, Japan, and Germany; by a lesser amount in the United Kingdom; and hardly at all in Australia. Outbound portfolio investments increased in all countries, with the largest increase as a share of GDP in the United Kingdom.

With the exception of the United Kingdom, the countries with positive net outbound FDI experienced growth in net outbound FDI as a share of GDP between 2000 and 2012, while net inbound FDI to Australia increased. Japan's net outbound portfolio investments increased as a share of GDP and Australia's net inbound portfolio investments increased. Germany, however, experienced only a modest increase in its net inbound portfolio investments, and the net inbound portfolio investments of the United States declined slightly. The United Kingdom was the outlier, moving from substantial positive net portfolio outflows in 2001 of about 30 percent of GDP to net inflows of about 7 percent of GDP in 2012.

These figures have some implications for the different constraints the five countries face in designing international taxation policies. Australia is a large capital importer, so it may be more 
concerned about how it taxes corporate income from production in Australia and the portfolio income of foreign investors than about its rules for taxing foreign-source income of Australian companies. In addition, relative to other countries, Australia has a larger natural resource sector and so relies more heavily on taxing income generated in that sector, much of which represents economic rents. The United States is the largest economy and one of the least exposed to trade and capital movements, so it has some-although not unlimited-ability to impose higher taxes than other countries do on US-source income of all corporations and, to a lesser extent, on the foreign-source income of US-based companies. Among the other countries, Japan is most similar to the United States, although the long-term economic stagnation in Japan and the small amount of inward FDI to Japan both suggest the country may need to focus on keeping tax rates low to encourage Japanese companies to invest more at home. Germany and the United Kingdomboth of which are members of the European Union (EU), with its free internal movement of people and capital-are highly exposed to trade and capital movements. Therefore, in designing tax policies, they must pay attention to how their taxes will affect both incentives to invest in their respective countries and corporate decisions on where to locate their headquarters.

\section{DIFFERENCES IN BUSINESS SECTOR AND INDUSTRY CHARACTERISTICS}

The distribution of economic activities across industries and business sectors appears broadly similar in the five countries, but some differences exist (table 3). Germany and Japan have much larger shares of value added in manufacturing (about 18 to 22 percent), compared with the United Kingdom, the United States, and Australia (about 7 to 10 percent). ${ }^{3}$ Australia has the largest share of value added in industry (including energy, but excluding manufacturing) of the five countries (approximately 12 percent, compared with less than 5 percent for each of the four other countries), which reflects its very large energy and mining industries. The United States, the United Kingdom, and Australia have much larger shares of value added in financial and insurance activities than Germany and Japan. ${ }^{4}$ The United States also has the largest share of value added (approximately 24 percent) in a category labeled "public administration, compulsory social security, education, and health," which probably largely reflects its relatively very high medical spending as a share of GDP.

\section{GENERAL TAX STRUCTURES AND FISCAL POSITION}

Among the five comparison countries and including subnational governments, the United States and Japan in 2012 raised the least revenue as a share of GDP (29 and 31 percent), while Germany raised the most at 45 percent (table 4). The United Kingdom and Germany spent the

\footnotetext{
3 The Organisation for Economic Co-operation and Development table from which these figures are drawn does not include valueadded data for the United States. We imputed value-added data for the United States by multiplying US employee compensation figures in each sector by the average ratio among the other four countries of value added to employee compensation.

4 The UK financial sector, however, has not been a major factor in the debate over corporate taxation in the United Kingdom in the past few years, where recent corporate tax cuts have been directed at the nonfinancial sector.
} 
most (just under 45 percent of GDP), while Australia spent the least (about 37 percent) of GDP. The United States, Japan, and the United Kingdom all ran large budget deficits (ranging from 8 to about 10 percent of GDP), whereas Australia had a much smaller deficit (under 4 percent of GDP) and Germany a slight surplus. Based mainly on prior-year deficits, Japan's net public debt stood at about 130 percent of GDP, whereas the United Kingdom and the United States had net government debt around 80 percent of GDP. Japan, however, has a positive external balance, largely because of its very high rate of private saving, which helps explain its large external financial balance. The ratio of net public debt to GDP was much smaller in Germany (58 percent) and Australia (11 percent).

These figures suggest that the United States, the United Kingdom, and Japan may face serious fiscal constraints that limit their ability to cut taxes on MNCs, unless they are willing to raise other taxes to address their budget shortfalls. ${ }^{5}$ These constraints, however, have not prevented the United Kingdom and Japan in recent years from reducing their nominal corporate tax rates or eliminating taxation of repatriated dividends ("going territorial").

The five countries differ substantially in their reliance on corporate taxation as a revenue source, with Australia raising about 20 percent of its receipts from the corporate income tax and Germany raising less than 5 percent (table 5 , based on national and subnational taxes). The United States raises a smaller share of its receipts from the corporate income tax (slightly under 10 percent) than does Australia and Japan, but a larger share than the United Kingdom and Germany. The United States raises a larger share of total (national and subnational) revenue on average than the other four countries from personal income taxes and property taxes and a smaller share from goods and services taxes (the latter because it is one of the few countries in the world without a nationwide sales or value-added tax). But Australia raises a larger share of revenue than the United States from personal income taxes, the United Kingdom raises almost as much from property taxes, and Japan raises only slightly more from taxes on goods and services. The United States does, however, have the highest statutory corporate tax rate (39.1 percent, including subnational taxes) among the five countries, while raising less corporate revenue as a share of GDP than all of the others except Germany (table 6). Among the other four countries, Japan has the highest statutory corporate rate (37 percent), and the United Kingdom has the lowest (21 percent), with Germany and Australia both at about 30 percent. ${ }^{6}$

\footnotetext{
5 The United Kingdom raised its value-added tax (VAT) rate and broadened its VAT base, and Japan is considering an increase in its VAT rate.

6 Effective tax rates can differ from statutory rates because of favorable capital-recovery rules and other tax preferences for business investment. The United States has a lower ratio of effective to statutory rates than some other countries but still has an effective rate above the average for the Organisation for Economic Co-operation and Development and about at the average for the Group of Seven (G7) (Hassett and Mathur 2011). Based on data reported in Hassett and Mathur (2011), we calculate that in 2010 the US average effective corporate tax rate was 74 percent of the statutory rate, compared with a ratio of 80 percent for the unweighted average of the four comparison countries and 83 percent for the un-weighted average of the G7 excluding the United States. The ratio of the marginal effective corporate tax rate to the statutory rate was 60 percent for the United States, compared with 68 percent of the un-weighted average of the four comparison countries and 74 percent for un-weighted average of the $\mathrm{G} 7$ excluding the United States.
} 
Income of corporate shareholders is taxed at both the corporate level and the individual level when paid out as dividends, so the tax burden on corporate shareholders reflects both levels of tax and differs depending on the income bracket of shareholders (table 7). The United States and Japan have always had "classical" corporate tax systems, which impose separate taxes on corporations and their shareholders. In the United States, the shareholder tax is imposed at a reduced rate. In Japan, an individual includes a dividend in total income, which is taxed at the individual's tax rate. Other countries have had various forms of "integrated" systems that allow shareholders to claim credit for corporate taxes associated with the dividends they receive. Germany, however, has repealed its dividend integration system, and the United Kingdom has reduced the tax credit that individual and trust shareholders receive to the basic dividend tax rate of 10 percent (while dividends are taxed at rates up to 37.5 percent). In contrast, Australia retains its full dividend integration system. In Australia, therefore, the combined rate on distributed corporate income is simply the top personal rate of 49 percent (including the temporary 2 percent budget repair and Medicare levies), though tax is collected partially at the corporate level. The combined rate reflects the fact that corporate income taxes are excluded from the personal income of individuals and the effects of any preferential rates for corporate dividends received by individuals. When all these factors are taken into account, the United States, at 57.6 percent, has the highest top nominal combined corporate-personal rate on dividends, despite the preferential treatment of dividends under the US federal personal income tax. ${ }^{7}$ The contribution of the corporate tax rate to the combined rate is the highest in Japan and the United States (74 and 68 percent, respectively) and the lowest in the United Kingdom (47 percent).

The dividend-level tax adds the most to the combined tax rate in the United Kingdom and the least in Japan. Most countries tax income of resident individuals on a worldwide basis but the income of resident corporations largely on a source basis. Because dividend taxes generally apply equally to both domestic- and foreign-source income, they have less effect on the location of investment than the corporate-level tax (Altshuler, Harris, and Toder 2010).

\section{RULES FOR TAXING BUSINESS INCOME}

One reason the United States raises relatively little revenue as a share of GDP from corporate taxes despite having the highest statutory corporate rate in the Organisation for European Cooperation and Development (OECD) is that a relatively large share of business activity in the United States comes from firms that do not pay corporate income tax. ${ }^{8}$ Since the early 1980 s, US

\footnotetext{
7 The top US federal rate on dividends is 23.8 percent, including the Medicare tax on net investment income, compared with a top income tax rate of 39.6 percent on earnings and self-employment income. State personal income taxes, however, add on average another 6.7 percentage points to the maximum personal rate on dividends.

8 A second reason that the United States raises relatively little revenue as a share of GDP from corporate taxes despite having the highest statutory corporate rate in the OECD is the extent of tax preferences it allows in relation to business income. On the basis of estimates and projections reported by the US Office of Management and Budget (2014, table 14.2, 210-15), we calculate that corporate tax expenditures, excluding international provisions, will reduce US corporate tax receipts by about 15 percent between fiscal years 2015 and 2019. Including international provisions would raise this figure to 23 percent, but the major international tax
} 
tax law has become much more flexible in its tax classification of business organizations. In response to various laws and regulations ${ }^{9}$ and the reduction in individual income tax rates since the early $1980 \mathrm{~s},{ }^{10}$ most businesses in the United States, accounting now for over 60 percent of business income, are today organized as flow-through enterprises that pay no corporate income tax. Instead, they allocate their income to their shareholders or partners, who include it in their total income subject to the personal income tax.

With some exceptions, however, most companies in the United States that are publicly traded on organized exchanges are still organized as taxable corporations. Important exceptions are real estate investment trusts (REITs) and publicly traded master limited partnerships, which are taxed as flow-through enterprises. Recently, the use of REITs has expanded because US Internal Revenue Service (IRS) rulings have permitted corporations to spin off more of their assets into these investment vehicles (see, e.g., Boos 2014).

We were unable to locate a source of comparative data on the shares of business income in different countries that come from businesses that pay a separate corporate income tax. Piecing together separately reported data in each country that may not be capturing exactly the same definitions (table 8), we estimate that the United States, among the five countries, has the lowest share of business profits that come from companies (including sole proprietorships) that are subject to a corporate profits tax (34 percent). Germany appears also to have a relatively low share of business profits subject to the corporate tax (45 percent). ${ }^{11}$ In contrast, although most of their businesses are organized as partnerships or sole proprietorships that do not pay a corporate tax, very large shares of income of business firms in Japan (87 percent), Australia (82 percent), and the United Kingdom (80 percent) are subject to their country's corporate income tax.

Although corporate revenue is less important in the United States as a share of revenue from business profits than it is elsewhere, the United States still needs to pay careful attention to interactions between its corporate and personal income tax laws. For example, a reduction in the US corporate income tax rate without a corresponding change in the top personal income tax rate could cause many businesses in the United States to switch from being partnerships or subchapter S corporations to being taxpaying C corporations. This switch in the form of business

expenditure, deferral, is less generous than the exemption of foreign-source income in the tax laws of the four comparison countries. Although the domestic tax preferences reduce the effective US corporate rate below the statutory rate, the effective corporate rate is also lower than the statutory rate in most other OECD countries, although less so. As noted in footnote 6, the ratio of the effective rate to statutory rates is slightly lower in the United States than it is in the four comparison countries, according to calculations from data reported by Hassett and Mathur (2011).

9 These regulations include liberalization of the qualifications for S corporation status and the promulgation by the US Treasury of "check-the-box" rules in 1996, which facilitated the growth in flow-through enterprises.

10 Before the 1986 tax reform, the top individual rate was higher than the top corporate rate. The Tax Reform Act of 1986 reversed that situation, reducing the top individual rate to 28 percent and the top corporate rate to 34 percent. Since then, the top individual rate has increased but remains only slightly above the top corporate rate (39.6 percent compared with 35 percent).

11 The German data come from online statistics posted by the German government statistics bureau, as cited in the notes to table 8. Erik Roeder of the Max Planck Institute for Tax Law and Public Finance informs us that, according to his calculations, the figure would be 50 percent if one took only industry from "trade and industry" into account but would be only 41 percent if one included income from self-employment and farming. 
organization would raise corporate revenue-but at the cost of an even larger reduction in personal tax revenue as business owners (especially owners of closely held businesses) took advantage of the new differential between the individual and corporate tax rates. For a discussion of the consequences of setting the top corporate rate below the top personal rate and possible policy responses to prevent individuals from using the corporate form to shelter their personal income from tax, see Halperin (2009). 


\section{HOW THE CURRENT US TAX SYSTEM WORKS}

All income earned by US corporations is subject to the US corporate tax regardless of whether it is earned at home or abroad, although the tax on most foreign-source income earned through a foreign subsidiary is deferred until the profits are repatriated as a dividend to the US parent corporation, and foreign income generally is not subject to state corporate income tax. This federal "worldwide" or "residence" approach to the taxation of corporate international income has become increasingly rare. All but seven OECD countries (Chile, Ireland, Israel, Mexico, Poland, South Korea, and the United States) have adopted systems that exempt most or all active earnings from foreign business activities from home-country corporate taxation. Many countries attempt to tax passive income earned by foreign subsidiaries from portfolio investments, although the extent to which this is done varies widely. Countries that do not tax the active foreign-source income of their corporate taxpayers instead of taxing active foreign-source income when repatriated are commonly referred to as having territorial tax systems. Calling this approach a dividend exemption system is more accurate, however, because the removal of homecountry tax liabilities on active foreign income is typically accomplished by exempting dividend remittances from foreign affiliates to home-country parent corporations from tax. ${ }^{12}$ The current US system has some features in common with a territorial tax system and for this reason is sometimes characterized as being a hybrid between a pure worldwide system (in which foreign profits are taxed when earned) and a pure territorial system, because foreign subsidiary profits are not taxed until distributed.

Understanding how the US system differs from the dividend exemption systems in the four countries we examine in this report requires a basic understanding of US tax law. What categories of foreign-source income are taxed and when? What tax-avoidance opportunities are available, and how easy are they to exploit? Does taxing the worldwide income of US corporations result in double taxation? Although it may seem exceedingly complex, the US system may be understood by studying the basic building blocks of any system for taxing income of MNCs.

This chapter is organized as follows. The next section briefly describes the building blocks of the US system. We then examine how the US system works in practice, how much revenue is raised, and from what types of foreign income it comes. As we will see, special features of the US system result in little revenue being raised from dividends that foreign affiliates pay to US parent companies. The final section examines how the US system differs from a hypothetical dividend exemption system. In particular, we discuss how the economic decisions of US MNCs might change if the United States were to adopt a dividend exemption system.

12 Some countries also exempt profits from foreign branches from home-country taxation. 


\section{THE BUILDING BLOCKS OF THE US INTERNATIONAL TAX SYSTEM}

The building blocks of the U.S. international tax system include:

- Rules regarding what types of foreign-source income are taxable by the home country and when that income is taxed.

- Provisions that are put in place to mitigate any double taxation of foreign-source income by the country where income is earned and the home country of the corporation earning the income. These provisions must be supported by rules that define whether income is treated as domestic or foreign and the extent to which overhead expenses of the home corporation that support both domestic and foreign investment are deductible against domestic income. These overhead expenses include interest payments, expenses for research and development (R\&D), and general and administrative expenses. As we will see, the United States is unusual in the extent to which it requires that its home multinationals allocate these types of expenses between domestic and foreign income instead of allowing them all to be claimed against domestic income.

- Rules that determine whether a corporation is a resident or nonresident taxpayer. Under the US system, resident corporations are subject to tax on their worldwide income whereas foreign-owned corporations are taxed only on domestic-source income.

In the US case, each of these building blocks consists of a detailed set of rules that have been put in place over the years to implement provisions originally adopted when international economic activity was a small part of the US economy. Each new generation of policymakers has added or modified provisions to protect the tax base and/or reduce any undesirable incentives created by the tax system and, in some cases, its interaction with other tax systems. These rules have been loosened and tightened over time in response to concerns expressed by corporate taxpayers about competitiveness on the one hand and about pressures on the tax base on the other hand.

\section{What Foreign-Source Income Is Subject to US Tax and When?}

Under the US system, all foreign-source income of US MNCs is subject to US federal (but generally not state) corporate tax. The time at which tax is due to the US Treasury on foreign earnings depends on how the MNC has organized its foreign operations. If operations are organized as branches (that is, they are not separately incorporated in the foreign country), then the United States taxes all foreign profits on accrual. In contrast, if operations are set up as subsidiaries (that is, they are separately incorporated in the foreign country), then US taxation of active foreign profits is generally imposed only when the subsidiary pays dividends to the US parent corporation. This delay in taxation until a subsidiary's profits are actually remitted is known as deferral. As a result of deferral, the timing of US tax on these profits is elective, much like the tax on capital gains. 
Deferral of US tax allows foreign business income of US MNCs to be taxed at a lower effective rate than it would be if it were earned in the United States if the foreign country's tax rate is lower than the US rate. When combined with financial accounting rules that effectively treat deferred earnings as permanently exempt, deferral also creates a lockout effect with associated efficiency costs. ${ }^{13}$ Corporations will engage in inefficient behavior (they will take actions that they would not find attractive were it not for the tax) to avoid the tax due on repatriation and associated reduction in after-tax book income. For example, a parent corporation that wants to invest in a project in the United States, distribute dividends to shareholders, or buy back its shares may borrow at home instead of remitting foreign profits in order to extend the deferral of US tax on foreign earnings. This maneuver allows the US parent to defer the US corporate tax but raises the cost of capital for domestic uses. Deferral also creates incentives for tax avoidance through income shifting.

The burden of the tax on foreign subsidiary dividends is a key issue for understanding both (a) the benefits and the detriments of moving to a dividend exemption system and ( $b$ ) the way the current system differs from dividend exemption. ${ }^{14}$ Pressure from US MNCs arguing that the burden was costly to their business operations and a desire by Congress to induce US MNCs to reinvest accrued foreign profits in the United States resulted in a repatriation tax holiday in 2005. Not surprisingly, pressure for a similar tax holiday surfaced not long after the holiday expired and has continued since. The burden of the tax on foreign subsidiary dividends includes both the actual tax paid on repatriation and the implicit costs of deferring income, which likely increase as retentions abroad grow. These implicit costs include, for example, the cost of using parent debt to finance domestic projects as a substitute for foreign profits (which will increase as debt on the parent's balance sheet balloons), payments to tax planners, forgone domestic investment opportunities, and foreign acquisitions that may not have been undertaken in the absence of the tax. Grubert and Altshuler (2013) use data from the Treasury tax files to derive an estimate of the cost of deferring foreign income that takes into account the growing stock of profits retained abroad after the holiday. Their work suggests that the implicit cost of the tax on foreign profits for a highly profitable company (one that has profit margins on sales in excess of 20 percent) is about 7 percentage points today.

\footnotetext{
13 Economists have long recognized that, under certain strong assumptions, including a constant tax rate on repatriations, US corporations should be indifferent to the timing of a foreign subsidiary's dividend distributions (Hartman 1985). US multinationals, however, may anticipate on the basis of history that rates will fall, making it advantageous to defer repatriation. Accounting rules create additional incentives to retain profits overseas. As a result, we believe that deferral does cause US corporations to hold substantially more earnings offshore than they otherwise would.

14 See Warren (2014) and Halperin and Warren (2014) for presentations of the simple analytics of deferral. Warren (2014) compares the tax advantage of retaining earnings in low-tax locations abroad and the tax advantage of investing in low-tax locations abroad under credit systems with deferral like the US and exemption systems. The simple models demonstrate that the advantage of deferral comes not from delaying the US tax on foreign-source income but instead from the lower tax rate on future profits earned abroad. The foreign earnings deferred abroad compound at a higher after-tax return than they would at home. That advantage remains under exemption. As Warren acknowledges, these results have been discussed in earlier work in the economic, legal, and finance literatures, but they have not been appreciated in many policy discussions comparing credit and deferral systems with territorial systems. As discussed previously, the restrictive assumptions underlying these models do not hold in practice. Accordingly, the analysis in this report is based on the available empirical evidence that finds a positive burden from lock-in resulting from the tax on repatriation of foreign earnings.
} 
Importantly, the two countries that most recently abandoned their worldwide systems and adopted dividend exemption systems - the United Kingdom and Japan-allowed corporations to move foreign profits from affiliates to parents without any home-country tax through subsidiary loans to, or investment in, parent corporations. ${ }^{15}$ In those countries, apparently parent corporations could access foreign profits relatively easily without paying home-country tax. The US tax code, however, would treat such loans or investments as distributions with respect to stock and subject them to US tax to the extent of unrepatriated earnings. Although we are not aware of any estimates for the United Kingdom or Japan similar to Grubert and Altshuler's (2013) estimates for the United States, our understanding of these provisions suggests that the burden of the tax on foreign dividends in those countries was smaller than it is in the United States.

The US tax code contains provisions designed to limit the ability of firms to avoid US taxes on certain types of foreign income by retaining it abroad in low-tax jurisdictions. These anti-tax avoidance provisions, referred to as controlled foreign corporation (CFC) rules and contained in subpart $F$ of the US tax code, generally limit deferral to earnings from active business investments abroad. US CFC rules deny deferral to earnings from financial assets (such as Eurobonds and other passive financial investments) and payments of interest, dividends, rents, and royalties from one CFC to a CFC in another jurisdiction. The American Jobs Creation Act of 2004, however, contained a temporary CFC look-through rule under which payments received by one CFC from a related CFC were not treated as currently taxable. ${ }^{16}$

In recent years, US MNCs have increasingly used hybrid entities to avoid the CFC rules and to lower tax payments to foreign governments without a corresponding increase in taxes paid to the US government. News stories have trumpeted the low tax payments of US MNCs generated by tax-planning techniques that make use of these entities. A hybrid entity may be one that is classified as a corporation from the host-country point of view and yet is disregarded as a separate entity or treated as a pass-through entity from a US tax point of view (or vice versa). Regulations made effective in 1997 greatly simplified the process of setting up hybrids. Those regulations are referred to as "check-the-box" rules because they allow MNCs either to identify an entity as a separate corporation or to "disregard" it as the unincorporated branch of another corporation (or treat it as a pass-through entity) by simply checking the box on a tax form. These regulations have made it much easier for US MNCs to benefit from tax-haven subsidiaries while avoiding the CFC rules.

To understand the benefit of using a hybrid, consider the following scheme. The parent company of a US MNC sends funds to a tax-haven affiliate, which then loans the funds to another affiliate in a high-tax host country. The high-tax affiliate pays interest to the tax-haven affiliate,

15 Section 956 of the Internal Revenue Code prevents companies from avoiding home-country taxation while implicitly receiving the benefits of the foreign earnings of their controlled foreign affiliates through loans or investments in US property by treating these transactions as constructive dividends. We are not aware of any other OECD country that has these types of rules in place. 16 The provision has been renewed and technically expired in 2013. In December 2014, Congress extended it again, but only through the end of 2014. 
which is deductible against local taxable income, thereby lowering the tax bill in the high-tax host country. ${ }^{17}$ The MNC checks the box on the high-tax affiliate so that the IRS treats it as an unincorporated branch of the tax-haven affiliate. The tax-haven and high-tax affiliates are considered separate corporations by the high-tax host country that grants a deduction for the interest going to the tax-haven company, but the transaction is disregarded for US tax purposes, which regards the tax-haven affiliate and the high-tax operation as one corporation. The interest payment escapes the CFC rules, and the parent company can defer US tax on the income it shifts in this manner from the high-tax country to the tax haven.

Hybrid entities can also be used to send dividends to a holding company in a country that exempts dividends from taxation. ${ }^{18} \mathrm{MNC}$ s frequently organize their foreign investments through holding companies. Without the use of a hybrid entity or application of the temporary statutory look-through rule, the intercompany dividends would generally be subject to current US tax. By electing to treat the dividend-paying company as a disregarded hybrid entity, tax planners can arrange for the dividend payments to escape US taxation because they are treated as transfers within a single entity and therefore disregarded for US tax purposes.

Hybrid entities may also be used to move income from intellectual property, such as patent royalties, from foreign subsidiaries in higher-tax countries to tax havens by making the payment of royalties from one affiliate to another disregarded. (The statutory look-through rule would treat the payment as active income, not included in current US taxable income, to the extent that the deduction is allocable to active-not passive-income.) Consider the following arrangement. A tax-haven entity engages in a cost-sharing agreement with the parent. It pays for part of the parent's R\&D project and acquires the right to license the resulting technology to foreign subsidiaries in high-tax countries (which manufacture goods using the technology) in exchange for royalty payments. The $\mathrm{MNC}$ has an incentive to underprice the cost-sharing payment made by the tax-haven entity and to overprice the royalty that the tax-haven entity receives. In this way, a large amount of income can be shifted to the tax haven. With check-the-box rules, royalty payments made by the high-tax foreign affiliate to the tax-haven entity that owns the technology can escape current US tax because the tax-haven entity and the high-tax affiliate can elect to be treated by the United States as a single subsidiary. As with the interest payment in the previous example, the royalty payment is deductible in the high-tax country without producing an offsetting amount of taxable income and thereby lowers the effective tax rate paid by the hightax affiliate.

In recent work using US Treasury tax return data, Grubert (2013) concludes that the checkthe-box rules may account for up to 2 percentage points of an approximate 5 percentage point

17 Host-country tax laws, such as thin capitalization rules, sometimes limit the ability to use the earnings-stripping technique described here.

18 For this technique to work, the country should have a tax treaty network that ensures low withholding taxes on dividends, or, if the dividend is paid among EU member countries, the dividend should qualify for exemption under the EU interest and dividend directive. 
reduction in the effective tax rates US MNCs paid on their foreign-source income between 1996 and 2004.

\section{How the United States Prevents Double Taxation}

When remitted to the parent, foreign profits are subject to home- as well as host-country income taxes. To alleviate the double taxation of this income, the United States allows corporations to claim credits for income taxes paid to foreign governments directly or by foreign subsidiaries on distributed earnings. These foreign tax credits can be used to offset US tax liability on foreignsource income. A limitation on the credit prevents US MNCs from using foreign tax credits to reduce US tax liabilities on income earned at home. The limit is the amount of tax that would be due if the foreign income were earned in the United States.

To understand how the credit and its limit work, consider a foreign subsidiary of a parent MNC that earns US $\$ 100$ subject to an effective foreign tax rate of 45 percent. Assume the subsidiary repatriates all foreign income as dividends as it is earned. Because the US tax rate is 35 percent, the foreign taxes paid with respect to the foreign earnings (US\$45) exceed the US tax liability (US\$35) on the US $\$ 100$ of foreign income. A parent corporation in this situation is said to be in an excess credit position because it has more foreign tax credits than can be claimed in the current year. ${ }^{19}$ This parent corporation owes no residual US tax on the US $\$ 100$. The same corporation would be said to be in an excess limitation position if it had earned the US $\$ 100$ in a country with a tax rate below the US rate. If the host-country rate were 25 percent, for instance, the parent would be faced with a residual US tax of US $\$ 10$ on remittance of the US\$100 dividend.

The foreign tax credit system allows firms to use excess credits from one source of active foreign income to offset US tax payments on income from another source. This procedure is called cross-crediting or averaging. Active and passive income are considered separately, which limits cross-crediting between these two categories of income.

To understand how cross-crediting works, assume that the MNC earns US $\$ 100$ of active income both in a country with a tax rate of 25 percent and in a country with a tax rate of 45 percent. Suppose all earnings are sent home to the parent as they are earned. Cross-crediting allows the US parent corporation to offset the US $\$ 10$ of US tax liability on the US $\$ 100$ repatriated from the low-tax affiliate against the US $\$ 10$ of excess credits on the US $\$ 100$ repatriated from the high-tax affiliate.

Cross-crediting means that excess credits generated by one type of foreign income can flow over to other income in the same category and shield that income from any residual US tax. Royalty payments from foreign affiliates to parents for the use of an intangible asset that the parent developed, while deductible abroad, are considered active foreign-source income instead

19 Under current law, excess credits can be carried back to offset any US tax payments on foreign-source income made in the previous year. Credits may also be carried forward without interest and used to offset US tax liability in the following 10 years. 
of domestic-source income even though the intangible asset was produced domestically. These payments may end up bearing no US tax if the parent has available excess foreign tax credits. ${ }^{20}$ As a result, some US corporations (those with excess foreign tax credits) pay no tax on royalty payments while others (those with excess limitations) pay full US tax on royalties. Note that under dividend exemption systems, royalties paid from foreign affiliates to parent corporations are treated as domestic income and are fully taxed at home (unless the home country imposes a preferential rate). Similar to royalty income, income derived from exports may not be fully taxed under the current US credit and deferral system, because US rules treat 50 percent of income from US-manufactured exports and 100 percent of export sales income as foreign-source income. As a result, US tax on this income is eligible for offset by foreign tax credits. Export income is generally treated as domestic income and is subject to full home-country tax in dividend exemption systems.

The foreign tax credit limit for each income basket is based on foreign income net of any parent overhead expenses (interest, $R \& D$ expenditures, general and administrative expenses). The idea is that these domestic headquarter expenses support income generation across the worldwide firm and should be so allocated. As mentioned previously, the US tax code contains a set of rules under which expenses are allocated between domestic and foreign income. These allocations, however, affect companies only if they cannot claim credits for all the foreign taxes they have paid. If a company has excess credits, allocation of expenses to foreign income increases US tax by reducing the foreign tax credit limitation and thereby reducing allowable credits. If the company does not have excess credits or is currently not repatriating income, the allocations have no effect on current US tax liability. ${ }^{21}$

\section{Residency Rules}

Under current law, residence is based on the place a business entity is organized. This rule may give businesses an incentive to establish their legal place of residence outside the United States to avoid the tax on dividend repatriations and to be in a better position to strip income out of the United States through intercompany debt. Some other countries use different rules to define residence for the purpose of income taxation. Typically, the tax residence of companies is based on place of incorporation (as in the United States), location of management and control, or a combination of the two. For example, in the United Kingdom and Germany, a company is a domestic resident if it is incorporated in the country or is managed and controlled in the country. Japan, like the United States, bases residence on the country of incorporation. A company is an

\footnotetext{
20 As Grubert and Altshuler (2013) note, the decline in foreign tax rates abroad and enactment in 2010 of new "anti-splitter" rules for the foreign tax credit are likely to decrease the amount of excess credits under the current US tax system. This change has important implications for company behavior and for understanding how such behavior will change should the United States move toward a dividend exemption system. Grubert and Altshuler assume in their effective tax rate simulations that the probability of a company having excess credits is only 20 percent.

21 In most territorial systems, allocations of home-country expenses to foreign income are very limited or nonexistent. There seems to be little recognition that this situation in effect subsidizes the foreign investment by allowing firms to deduct costs at homecountry rates that generate tax-free foreign income. In contrast, if in a territorial system home-country expenses allocated to exempt income were disallowed, there effectively would be full home-country taxation of domestic income and a zero tax rate on foreign income.
} 
Australian resident if it is incorporated in Australia or carries on business in Australia and has either its voting power controlled by resident shareholders or its central management and control in Australia.

\section{DOES THE UNITED STATES COLLECT CORPORATE TAX REVENUE FROM THE FOREIGN PROFITS OF US FIRMS?}

Given the deferral and credit features of the current US system, an important question to ask is the extent to which the tax system collects corporate tax revenue on foreign-source income. In recent work using Treasury tax data, Grubert and Altshuler (2013) estimate that US $\$ 32$ billion of revenue was collected on all corporate foreign-source income in 2006. This amount was approximately 9 percent of 2006 corporate tax revenues but less than 4 percent of all foreignsource income of US MNCs (including profits deferred abroad, but before allocated parent expense). US taxes paid on dividends account for a very small portion of this revenue. The remainder comes from taxes on royalties, portfolio income, export income, and income from foreign branches.

Using Treasury tax return data from 2006, Grubert and Altshuler (2013) estimate that total US tax revenue would increase by about US $\$ 1$ billion if dividends were removed from taxable foreign income. This static revenue exercise demonstrates the extent to which companies are able to absorb taxes due on low-tax active income, such as royalties, with excess credits from dividends from high-tax countries. Assume, for example, that a company pays US $\$ 100$ of dividends that are associated with US $\$ 45$ of foreign tax. Assume that this company also receives US $\$ 100$ of royalties. With cross-crediting, the US $\$ 35$ of US tax due on royalties is reduced to US $\$ 25$. If dividends were exempt from taxation, the United States would collect the full US $\$ 35$ on the royalty income, and US tax revenue would increase by US $\$ 10$.

\section{HOW WOULD MNC BEHAVIOR CHANGE IF THE UNITED STATES ENACTED A DIVIDEND EXEMPTION SYSTEM?}

The current US system induces several behavioral responses that distort business decisions and waste resources. The system provides incentives to invest in tangible and intangible capital in some locations instead of others, to engage in costly strategies to avoid the tax on foreign dividends, and to shift reported income from high- to low-tax locations by using inappropriate transfer prices or paying inadequate royalties. Where the tax burden under US rules exceeds what could be achieved through a non-US parent structure, pressure exists to change the parent corporation's domicile to a foreign jurisdiction. Legislation adopted in 2004 restricts many forms of these transactions (called inversions) by making them ineffective. However, a recent wave of apparently tax-motivated inversions through mergers with foreign companies suggests that the current US system continues to affect decisions regarding whether to remain a US resident corporation. The Congressional Research Service recently released a list of corporate inversions 
since 1983 (Marples and Gravelle 2014). According to the Congressional Research Service, 47 companies have given up US tax residence in the past decade (up from 29 between 1983 and 2003) with 34 making this move since $2009 .{ }^{22}$

To what extent does dividend exemption change these incentives? As mentioned previously, a key issue is the burden of the tax on subsidiary dividends, which seems significant. Under dividend exemption, repatriation taxes would create no burden, but royalties paid to parent corporations would be fully taxed (unless provisions were included to tax those payments at preferential rates). How dividend exemption ultimately affects location and income-shifting incentives, however, depends on the details of the exemption system adopted. Will the system include expense allocation rules? Will the new tax system include provisions designed to prevent companies from shifting income abroad and eroding the tax base? For example, draft proposals of dividend exemption systems from Dave Camp, then chair of the House Ways and Means Committee, and Max Baucus, then chair of the Senate Finance Committee, included provisions that would impose a minimum tax on some forms of foreign earnings to combat potential base erosion. ${ }^{23}$ Although minimum taxes can take different forms, the idea is to decrease the benefits of tax havens by forcing companies to pay current US tax at some rate (typically less than the US rate) on some or all foreign earnings. ${ }^{24}$ Even under dividend exemption proposals with serious base erosion provisions, however, an incentive would remain to reinvest earnings offshore in active business operations if the effective tax rate on reinvested earnings were lower than the US effective tax rate. An incentive would also continue to exist for some US firms to change domicile if US tax rules limiting the scope of the exemption were stronger than similar rules in the competitor countries and residence rules were not modified to address these incentives. ${ }^{25} \mathrm{As}$ with almost all issues of tax design, the details of the rules affect incentives.

\footnotetext{
22 A recent flurry of corporate inversions has been driven by (1) a desire to avoid US tax on CFC earnings held offshore, (2) the use of earnings stripping to reduce US taxes, and (3) the prospect of avoiding US CFC rules on future foreign earnings (Shay 2014). On September 22, 2014, the IRS slowed down some inversions in process by issuing Notice 2014-52, published in Internal Revenue Bulletin 2014-42 (October 14, 2014), which restricts the ability to use CFC earnings held offshore. The notice suggests that further guidance may be issued restricting earnings stripping, but such guidance has not been issued to date.

23 Unless drafted broadly, such anti-avoidance proposals are potentially subject to relatively standard strategies to avoid their reach. See Shay, Fleming, and Peroni (2013). The Camp draft proposal left a variety of potential loopholes.

24 See Grubert and Altshuler (2013) for a detailed analysis of minimum taxes.

25 Some commentators have suggested that, similar to Australia, the United States should impose rules that take account of whether a majority of shareholders are US resident if the corporation carries on US business activity (Fleming, Peroni, and Shay forthcoming).
} 
This section of the report examines how four countries that use a territorial or exemption system for taxing foreign business income (i.e., FDI income) design their rules. Two of these countries have long had some form of exemption regime for foreign business income (Germany and Australia). The other two have recently shifted from a worldwide (credit and deferral) system to a system that exempts dividends from foreign subsidiaries alone (Japan) or a system that exempts both subsidiary dividends and active foreign business income earned through a foreign branch (United Kingdom).

The objectives of this section are to describe how these countries structure their exemption systems for foreign business income and to assess whether the United States can learn any lessons from their approaches. We provide a brief background on each country's corporate tax system. Each country has its own tax culture and legal, economic, and historical context in which its corporate income tax has developed. These factors have influenced each country's approach to taxation of both domestic- and foreign-source income of corporations. We then describe the corporate tax structure, including the exemption system used and anti-abuse and other rules that seek to limit, directly or indirectly, the benefit of exemption. ${ }^{26}$ Finally, we summarize our observations regarding the country's approach to exemption of foreign income.

Although transfer pricing is a critical source of pressure on any exemption system, we do not discuss transfer pricing rules, documentation, or enforcement in this report. All of the countries involved use the arm's-length method and generally follow OECD transfer pricing guidelines. We take it as given that profit shifting is ubiquitous whenever significant rate differentials exist that can be taken advantage of through the use of related-party structures. The United States already struggles with transfer pricing enforcement, and the pressure would be exacerbated with the reduced frictions of an exemption system. We have not seen evidence that other countries have found approaches that mitigate these pressures. An analysis of transfer pricing issues, while interesting, would require substantial empirical work that is beyond the scope of this report.

We approach what can be learned from other countries' exemption systems with caution. ${ }^{27}$ What can be learned from a comparison of another country's rules for taxing a

\footnotetext{
26 Although developed countries' exemption systems have broadly common patterns, they also differ in important details. Our description of the systems in the four countries is limited in scope. For each country's corporate tax system, we describe (1) when a corporation is considered tax resident, (2) what the corporate tax rate is and how dividends are taxed, (3) how active foreign business income and dividends from foreign subsidiaries are taxed, (4) what income is taxed under CFC rules, and (5) what principal rules (in addition to CFC rules) are used to limit the benefits of the exemption for active foreign business income.

27 Scholars have discussed at length whether comparative law is purely instrumental or whether it also has a broader scope that allows comparisons of legal systems. See Valcke (2004). Our objective is explicitly instrumental: What have been the experiences of other countries using exemption or territorial systems? To what extent are their experiences relevant to the United States, and to what extent are they not? Should any approaches to taxing foreign income be avoided, and are any approaches worthy of copying in the context of US tax policy objectives?
} 
corporation's foreign income has limits. Comparative tax analysis is particularly hazardous when it focuses on a discrete part of a country's income tax system without taking account of how that part fits into the country's overall fiscal and income tax structure. ${ }^{28}$ Acknowledging these limitations, we seek to determine what the United States can learn from other countries' experiences.

\section{THE UNITED KINGDOM}

\section{Background: UK Corporate Taxation before 2000}

Starting in the 1970s, the United Kingdom partially integrated its corporation tax with its individual income tax by allowing a credit against the individual income tax on dividends for a portion of the dividend. To ensure that some corporate tax had been paid, the United Kingdom imposed an advance corporation tax (ACT) when dividends were distributed to UK residents, which offset the shareholder tax (colloquially, the arrangement was effectively considered a refund of ACT) and which also could be used to offset corporate tax. Under pressure from other countries, particularly the United States, the United Kingdom also allowed some ACT refunds to residents of certain treaty partners (including the United States). In the 1980s, the Thatcher government initiated what (outside the United States) has become an ongoing global trend of corporate tax rate reductions.

The United Kingdom also taxed worldwide income of its resident companies, including dividends from foreign (non-UK) subsidiaries, and allowed a credit for foreign taxes paid on income earned directly and with respect to earnings distributed as dividends from foreign subsidiaries. Although the United Kingdom nominally limited foreign taxes to the tax paid on foreign income on a per item basis, many UK companies used Dutch holding companies as a pooling mechanism to circumvent this restriction so that the foreign taxes were in effect pooled at the Dutch holding company and allowed as a credit against the UK tax on the dividend income. The ACT ensured that a UK corporate-level tax would be collected when foreign earnings were distributed to shareholders.

The United Kingdom had middle-of-the-road CFC legislation that, on the one hand, operated on an entity basis and caused all of a CFC's income to be taxed when it applied but, on the other hand, did not apply if the CFC carried on meaningful business activity (except with respect to financial income). Importantly, UK companies could easily circumvent anti-avoidance rules that were intended to limit repatriation of untaxed earnings by CFCs for use by UK affiliates. For this reason, UK companies, though nominally operating under a deferral regime like that in the United States, did not have "trapped" foreign earnings - at least insofar as the earnings could be loaned back to the United Kingdom without triggering tax. Indeed, in most cases, the

28 Arnold (2012, 473-74) comments: "Readers should be skeptical about drawing conclusions from any comparison of discrete aspects of countries' tax systems. Pieces of a tax system can be properly assessed only in the context of the system as a whole." 
deduction for interest by the UK affiliate was not offset by an income inclusion under the UK CFC rules. Eliminating upstream loans contributed to the UK view that shifting to a territorial tax system along with adoption of a worldwide debt cap would raise revenue rather than lose revenue.

\section{Drivers of Change: EU Law Constraints and Inter-country Tax Competition}

By the 21st century, several factors were prominent in causing the UK regime for taxing business income to change. Two central factors were constraints of EU law under European Court of Justice (ECJ) case law and tax competition from neighboring EU countries (Ireland, Belgium, the Netherlands, and Luxembourg, as well as Switzerland). ECJ interpretations of the EU treaty's single-market provisions severely restricted the ability to apply different tax rules to UK and EU residents, irrespective of how the non-UK resident was taxed in his or her home country. Hence, the United Kingdom could no longer allow ACT credits to its residents without making them available to residents of other EU member states as well. To avoid allowing ACT refunds to residents of all other EU member states, the United Kingdom effectively repealed its imputation credit system and instead mitigated double taxation of corporate income by reducing the rate of shareholder tax on dividend income in its personal income tax system. ${ }^{29}$ (Another important factor supporting repeal was the revenue cost of ACT allowing refunds to tax-exempt UK entities.) In 2009, the United Kingdom adopted a corporate dividend exemption system that eliminated UK tax on foreign dividends of UK MNCs.

Furthermore, an ECJ case of September 12, 2006, Cadbury Schweppes v. Commissioners of Inland Revenue, limited the application of EU CFC regimes to controlled companies in member states as follows: $[A]$ national measure restricting freedom of establishment may be justified where it specifically relates to wholly artificial arrangements aimed at circumventing the application of the legislation of the Member State concerned." The EU "wholly artificial arrangement" standard substantially restricts the scope of a CFC regime so that it will apply, if at all, only to obvious tax avoidance schemes.

This development, combined with substantial resistance to proposals to strengthen UK CFC rules by UK companies (including a series of company expatriations to other countries), resulted in adoption in the Finance Act 2012 of what was billed as a "competitive" CFC regime. The philosophy of the new CFC regime is that profits should follow economic activity and "substance" (referring to indicia of real economic activity), but, most important, these tests will be applied to the extent the profits otherwise would reflect UK economic activity. The target is to protect the UK tax base and not the rest of the world. EU law constraints also precluded a response to inversions along the lines of rules adopted in the United States that block certain

29 In 1999, the United Kingdom substantially cut back its corporate tax integration regime. It reduced its dividend tax credit to oneninth of a dividend, which, for fiscal year 2013/14, satisfied an individual's tax liability at the basic rate of 10 percent on dividends up to $£ 32,020$. The credit is not refundable if the liability is less. Larger dividends are taxed at rates of 32.5 percent to 37.5 percent (compared with rates on compensation income in comparable brackets of 20 percent, 40 percent, and 45 percent). 
inversions by treating as a US tax resident a new foreign parent company that, following inversion, has more than 80 percent continuing ownership by shareholders of the US company. ${ }^{30}$

The prior Labour government initiated consultations on reform of the CFC rules and exemption of foreign branch income. However, it was the Conservative government of Prime Minister David Cameron, operating in coalition with the Liberals, that took the position that a more positive environment for business was an important element in responding to the financial crisis and carried the process further by including tax rate reductions. The coalition government reduced the corporate tax rate and introduced a new "patent box" regime providing a reduced 10 percent tax rate on intangible income. ${ }^{31}$

\section{UK Corporate Taxation Today}

Residence and structure. The United Kingdom treats a corporation as tax resident if it is organized as a UK corporation or is controlled and managed in the United Kingdom. The United Kingdom generally imposes corporate tax on profits in excess of $£ 1.5$ million (about US $\$ 2.5$ million) at a rate of 21 percent for fiscal year 2014. The rate is scheduled to decrease to 20 percent in 2015.

The dividend exemption system was enacted in 2009 and was allowed to apply to distributions of foreign earnings prior to the effective date. Broad categories of dividends that were received after July 1, 2009 (whether from UK or non-UK companies) qualified for exemption from shareholder tax in the hands of large and medium-size companies (and in the hands of small companies meeting certain conditions). 32 A resident UK company generally is subject to tax on income earned through a foreign branch, but since 2011, in certain circumstances, the company may elect to exempt foreign permanent establishment profits (and disallow losses).33 Capital gains realized by a substantial corporate shareholder on the sale of a substantial shareholding of a trading company or the holding company of a trading group also are exempt.

Where foreign income is taxable, a credit may be allowed for foreign income taxes. Generally, foreign taxes with respect to foreign dividends that do not benefit from the dividend exemption are allowed against UK tax on such dividends.

\footnotetext{
30 Inversion transactions have continued in cases where a US company acquires a foreign company under a new foreign parent company and the former shareholders of the US company own less than 80 percent of the post-combination company. Recently, the US Treasury has issued a notice that restricts benefits from an inversion and has suggested that additional actions will be coming. See IRS Notice 2014-52 of September 22, 2014, published as Internal Revenue Bulletin 2014-42 (October 14, 2014).

31 Companies engaging in inversions also cited the "high" 28 percent UK corporate tax rate as a reason to move.

32 A series of rules constrain the scope of the distribution exemption. To be exempt, the distribution must fall within an exempt class of distributions. The two classes of exempt distributions relevant to large and medium-size corporations are (1) distributions from controlled companies and (2) distributions with respect to nonredeemable ordinary shares. This report does not address small corporations, but the limitation on dividend exemption for small companies is thought to make it harder for small "mom and pop" taxpayers to be drawn into income-shifting schemes. Generally, the exemption is not allowed if the distribution has certain interestlike features or if the distribution is deductible by the distributing company and certain other anti-avoidance rules may apply. $33 \mathrm{It}$ is also possible for a corporation to elect not to apply dividend exemption to a distribution.
} 
CFC rules and other limitations on benefits of exemption. For periods beginning on or after January 1,2013 , the United Kingdom has revised its CFC rules. Very generally, the UK rules are designed to ascertain whether a CFC holds assets or bears risks under an arrangement whose main purpose (or one of whose main purposes) is to reduce or eliminate the liability of any person for UK tax or duty. The rules are elaborate but exclude from their reach active business income and much financing income. There also are broad carve-outs from CFC income for CFCs that are organized and taxed in a long list of countries (not including most pure tax havens and certain preferential regimes in other countries). ${ }^{34}$ The rules apparently conform to the ECJ's decision in Cadbury Schweppes, which limited the application of CFC rules to CFCs in other EU countries unless a very high abuse standard was satisfied.

A worldwide debt cap regime, adopted effective for periods beginning on or after January 1,2010 , limits the available aggregate deduction for interest (or similar) payments to the consolidated gross finance expense of the group. There are anti-avoidance rules (unallowablepurpose rules and anti-arbitrage rules) that can deny deductions for debt raised to make investments offshore that generate tax-exempt dividends. For an intermediate holding company owned by a foreign parent, the UK also imposes thin capitalization rules.

\section{Summary: Reduced Taxation of Foreign Business Income}

The decision by the United Kingdom to shift to a dividend exemption system appears to be in response to (1) tax competition by European countries (Ireland, the Benelux countries, and Switzerland); (2) requirements to satisfy ECJ case law interpreting EU treaties; and (3) the recession brought on by the 2008 global financial crisis. The UK response to these developments in terms of taxation changes has been to adopt a low corporate tax rate, reduced rates of shareholder taxation, and an elective territorial corporate tax base with limited antiabuse rules directed at protecting solely UK business activity.

Because of the ability under prior law to make upstream loans of offshore funds, the UK shift to an elective territorial regime was not driven by the objective of using untaxed offshore earnings more effectively in the United Kingdom. The UK government was pressured to revise the CFC rules after well-known companies asserted that a proposal to impose stronger CFC rules was a major reason for their decision to establish a domicile outside the United Kingdom. Constraints of case law interpretation of the EU treaty also required the United Kingdom to relax its CFC rules in relation to EU CFCs. Furthermore, EU law has prevented the United Kingdom from adopting defensive measures against corporate expatriations similar to measures in the United States. ${ }^{35}$ The UK approach to protecting the boundaries of its exemption system forgoes

\footnotetext{
34 For example, Luxembourg is on the list of good countries, except for CFCs using its 1929 holding company regime or a captive reinsurance regime. However, leaked Luxembourg rulings disclosed on the website of the International Consortium of Investigative Journalists suggest that Luxembourg tax-avoidance planning not using the excluded 1929 holding company and reinsurance regimes has been broadly available to UK companies, including, for example, GlaxoSmithKline, the Guardian Group, and British American Tobacco, without running afoul of the UK CFC rules. See Galizia et al. (2014).

35 US rules, however, as we have recently seen, are not fully effective, because they do not restrict expatriations resulting from certain corporate combinations.
} 
concerns about foreign-to-foreign profit shifting by UK companies (as opposed to companies shifting profits out of the United Kingdom) and about low foreign tax regimes that induce investment from UK-based firms. ${ }^{36}$

The United Kingdom has expanded its corporate tax base and reduced the benefits of corporate integration while reducing tax rates on corporations and shareholders. Partnerships and other tax pass-through entities are relatively little used because of limitations of UK partnership law and practice. The United Kingdom is a large, but far from dominant, economy and a member of the EU single market, which imposes legal and tax competition constraints on its ability to protect its domestic corporate tax base and to defend against income shifting abroad. Those factors may explain in part its approach of combating tax competition by using (elective) exemption of foreign business income while reducing marginal rates to mitigate incentives to shift UK income offshore.

\section{JAPAN}

\section{Background}

Japan's corporate income tax has been a substantial source of revenue notwithstanding long periods of slow economic growth since the 1990s. In 2011, corporate income tax was 12 percent of all government revenue, and it is a significant portion of the revenue of prefectures and municipalities (Masui 2010). This may partially explain the persistence of relatively high rates even after recent rate reductions.

Large corporations currently are subject to a national corporate tax rate of 25.5 percent. When enterprise and municipal taxes are taken into account, and after the recent early termination of the reconstruction tax surcharge, the combined rate on a large corporation is approximately 35.6 percent, down from a combined rate of 38 percent in 2012. The government of Prime Minister Shinzō Abe would like to further reduce the corporate tax rate, but the size of government public debt, now about $¥ 1$ quadrillion (US\$10 trillion), limits options that would result in net revenue losses.

A notable feature of the Japanese tax environment is a compliant international taxplanning culture. Advisers say that, even today, the typical Japanese multinational in-house tax department is devoted mostly to tax compliance-that is, preparing tax returns and other documents necessary to comply with the tax laws. Although changes in attitudes are occurring, many Japanese companies consider paying taxes a matter of loyalty, and the amount of taxes

36 For example, GlaxoSmithKline, a UK parent company, reported in a petition contesting an IRS adjustment that it had in place a US \$13.5 billion intercompany debt to a US affiliate from a Swiss affiliate. Although the evident effect was to shift income from the United States to Switzerland, the IRS later conceded its proposed adjustment and, apparently, UK rules did not frustrate this planning. 
paid are considered a measure of the company's success. ${ }^{37}$ Japan uses informal as well as formal enforcement techniques to encourage compliance.

\section{Drivers of Change: Economic Stagnation, High Corporate Tax Rates, and Unrepatriated Offshore Earnings.}

In 2007, a large corporation faced a combined statutory rate of close to 40 percent. Moreover, in 2006 , Japanese corporations held offshore about $¥ 17$ trillion (approximately US $\$ 150$ billion) in foreign subsidiary earnings. Japan had no statutory rule against lending offshore earnings to a Japanese affiliate, but such lending was apparently not done with any frequency. This situation would be consistent with profits being associated with real economic activity and either not requiring material redeployment or carrying sufficient foreign tax credits to mitigate tax concerns regarding redeployment.

A study group of industry representatives, academics, and ministry observers convened in May 2008 by the Ministry of Economy, Trade, and Industry proposed in August 2008 to exempt foreign dividends instead of taxing the dividends and allowing a credit for foreign taxes, which had been the rule since 1962. The Government Tax Commission included in a policy recommendation in November 2008 a provision allowing "enterprises to be able to repatriate the relevant amounts at an appropriate time." It was felt that a failure to repatriate the profits to Japan raised the risk that $R \& D$ activities and jobs would be shifted overseas, while the repatriation of profits would encourage $R \& D$ and capital investment in Japan and lead to further growth in Japan. A second major objective was to make Japanese multinationals more competitive and a third objective was to simplify the foreign tax credit system. ${ }^{38}$

The legislative change to a dividend exemption system and repeal of the indirect foreign tax credit happened in record time at the height of the global financial crisis. Encouraged by the UK shift to a dividend exemption system, Japan wanted to encourage companies to repatriate earnings to improve the Japanese economy at a time of economic stress (Masui 2010). Offshore earnings accrued prior to the effective date were allowed to qualify for exemption without further tax.

\section{Japanese Corporate Taxation Today}

Residence and structure. A company with its head office or principal place of business in Japan is considered a Japanese tax resident and is taxed on its worldwide income. Japan taxes corporate profits at the corporate level and when they are distributed to shareholders. The national corporate tax rate on large companies is 25.5 percent, and localities add additional tax to bring the combined burden to an effective rate of 35.6 percent. ${ }^{39} \mathrm{~A}$ domestic dividend to an individual

37 See the comments of Gary Thomas, cited in Toder (2014). 38 See the comments of Gary Thomas, cited in Toder (2014).

39 A small or medium-size company is a company whose capital is not more than $¥ 100$ million (about US\$930,000), unless the company is owned directly or indirectly by one large company (a company whose paid-in capital is $¥ 500$ million or more, about 
is subject to withholding at 20.42 percent, and the dividend is included in total income. A Japanese corporate shareholder owning 25 percent for six months or more of the shares in another Japanese corporation is exempt (after a deduction of interest expense) from tax on the dividend income. A domestic dividend from a 100 percent group company is exempt from tax without any reduction of interest expense.

For fiscal years beginning on or after April 1, 2009, foreign subsidiary dividends paid to a Japanese company are 95 percent excluded from taxable income if the Japanese company has owned at least 25 percent of the foreign subsidiary for six months or more. The prior indirect foreign tax credit was repealed. The 5 percent taxable amount is a substitute for disallowing expenses allocable to the foreign dividends. Gains from the sale of stock in a foreign subsidiary are fully taxable.

CFC rules and other limitations on benefits of exemption. Japan has CFC rules that cause a 10 percent Japanese shareholder of a designated tax-haven subsidiary to be taxed on its share of the subsidiary's taxable earnings. A designated tax-haven subsidiary is a foreign company that is more than 50 percent owned, directly or indirectly, by residents of Japan and that is subject to an effective tax rate (under Japanese tax accounting) of 20 percent or less.

Taxable earnings include certain categories of passive income and active income that are not excluded under an active business income test. The active business income test is elaborate but generally excludes non-passive income if the subsidiary maintains a place of business in the country of its head office that is sufficient to carry on its business, carries on business with its own management, and meets an applicable standard for dealing with unrelated parties or doing business in the country of its head office. These rules allow taxpayers to earn low-taxed active business income in a broad range of circumstances.

In recent years, Japanese field examiners have reportedly sometimes applied "donation" rules, which deny deductions for, or impute income to, corporate taxpayers to deal with certain cross-border transactions that, in the examiners' view, may be difficult to address effectively with transfer pricing regulations. The criteria for applying these rules are quite vague, leading to considerable uncertainty for any taxpayer planning a cross-border transfer of a business or of intangible property. This enforcement development has had a chilling effect on potentially abusive transactions.

\section{Summary}

After two decades of economic stagnation interrupted by brief periods of growth-a situation that can be attributed to a wide range of economic and policy factors-Japan has been

US \$4.65 million) or unless 100 percent of the shares of the company are directly or indirectly held by two or more large companies in a 100 percent group. For fiscal years beginning on or before March 31, 2014, an additional corporate reconstruction tax of 10 percent of the corporate tax liability applied, which increased the national corporate tax rate to 28.1 percent, but the corporate reconstruction tax was terminated a year early, effective for fiscal years ending after April 1, 2014. 
undertaking a number of changes to its economic system. The timing and speed of the shift to a dividend exemption system was in the context of an urgent economic crisis and the belief that relief from residual Japanese taxation of earnings would increase distributions that would trigger domestic economic growth. The shift to exemption was preceded by corporate tax rate reductions and followed by further attempts at corporate tax reductions as part of the Abe government's more aggressive efforts at structural economic changes.

Despite Japan's fiscal pressures, the country's CFC rules were strengthened only slightly, which suggests that income shifting abroad has not been a major concern to policymakers. Possibly the perceived history of Japanese corporate taxpayer compliance, combined with the effectiveness of informal enforcement measures, has played a role in mitigating policymakers' concerns regarding the risks of foreign dividend exemption to the domestic corporate tax base.

\section{GERMANY}

\section{Background}

From 1977 until 2000, the Federal Republic of Germany ${ }^{40}$ maintained a fully integrated split-rate corporate tax system, with a lower rate on distributed profits than on retained earnings. As in the case of the United Kingdom, the practical implications of ECJ legal interpretations of EU law effectively forced a shift to a classical approach to corporate taxation, with intercompany exemptions for resident corporate shareholders. For individuals, if German shares are held as business assets, 60 percent of dividends are included in taxable income (otherwise a flat 25 percent rate applies). Until 2001, Germany provided exemption for foreign dividends by treaty only. Germany often protects its treaty relief for outbound investments with so-called switchover clauses. Such clauses, in prescribed circumstances (including potential abuse cases), require full taxation with a credit for foreign tax in lieu of exemption.

The division of taxation in Germany between the federal level and the states is an important feature of the design and enforcement of German tax rules. The component of the business income tax at the municipal level is imposed on an adjusted base of corporate income at rates that depend on the municipality's municipal coefficient (which is multiplied by a basic rate of 3.5 percent). The average business income tax rate at the subnational government level is 14 percent, which since 2008 is nearly the same rate as the federal corporate tax rate. The states also administer the German federal tax. Germany has quite strict rules limiting tax benefits and triggering realization in a range of cases it considers necessary to protect its tax base. It also has adopted a general anti-avoidance rule. Moreover, unlike the United States, Germany passes protective measures on a regular basis to keep up with developments in the market.

40 The Federal Republic of Germany reunified with the former German Democratic Republic in 1990, adding five new East German federal states to the 11 West German states. Much of the discussion of German tax law in this section is based on Perdelwitz (2014, sections 1.1 .1 and 1.13). 


\section{German Corporate Taxation Today}

Residence and structure. A German resident company formally is subject to tax on its worldwide income, though as will be discussed foreign subsidiary dividends now are exempt under domestic law (and foreign branch income earned in a treaty country is exempt by treaty), subject to limitations under CFC legislation. A company is resident in Germany for corporate income tax purposes if it has either its legal seat or its place of management in Germany. All entities organized under German commercial law are required to have their legal seat in Germany and therefore are considered German tax resident. If a German corporation transfers its legal seat or place of effective management outside of the EU or European Economic Area (EEA) so as to not be subject to worldwide taxation, it is deemed liquidated, resulting in a deemed disposition of assets and recognition of unrealized built-in gains. Similarly, the transfer of assets to a foreign permanent establishment triggers realization, except that if the transfer is to an EU country, the amounts are recognized over five years (Sieker 2014).

A non-German company can be tax resident if its place of management is in Germany. The place of management generally is considered to be the place where individuals who have final authority to make decisions concerning management of the company's everyday business are located.

The federal corporate tax rate was reduced in 2008 to 15 percent, which increases to 15.83 percent when the solidarity surcharge of 5.5 percent is applied. ${ }^{41}$ Combined with a municipal trade tax (the local component of the corporate income tax) that varies in rate but generally averages 14 percent, the combined corporate tax burden on domestic income is approximately 30 percent.

Along with the solidarity surcharge, a withholding tax of 26.38 percent is imposed on distributions of dividends by a German corporation. This tax is generally final for resident individual shareholders who hold the shares as an investment (and not as a business asset). The withholding tax can be credited against corporate income tax imposed on a resident corporate shareholder, however. If a resident corporation owns a direct interest of 10 percent or more, the dividend will be exempt whether the distributing corporation is German tax resident or nonresident. Five percent of the amount of the dividend is added back to income as a proxy for disallowed deductions, and deductions otherwise are allowed in full (interest is subject to a thin capitalization rule described later). The dividend may not be deductible to the paying company. Because of this participation exemption, foreign withholding tax on foreign-source dividends received by a German corporation is not creditable in Germany.

CFC rules and other limitations on benefits of exemption. Germany uses a series of anti-abuse rules to limit aggressive tax planning where taxpayers try to shift taxable income abroad. These rules

\footnotetext{
41 The solidarity surcharge is imposed on the corporate tax due after credits. It was imposed to cover the costs of integration of East Germany into the Federal Republic.
} 
include controlled foreign company rules, thin capitalization rules, tough "exit tax" rules applying to transfers of business functions abroad, "subject to tax" and switchover clause treaty protections, and a general anti-avoidance rule. ${ }^{42}$

Germany's CFC rules apply to certain retained passive earnings of an intermediary foreign company that is more than 50 percent owned, directly or indirectly, by one or more German residents if the passive income is subject to a foreign tax rate of less than 25 percent. Passive income is considered to be any income not covered in the active income category determined under the CFC rules. In particular, it includes royalties and interest. The CFC rules will not apply to a company if it is resident in an EEA country, it carries on genuine business activity, the passive income is connected to the activity, and the EU Mutual Assistance Directive or a similar agreement is available in the EEA country.

Generally, but subject to a series of exceptions allowing greater interest deductions, interest expense may not exceed interest income plus 30 percent of income based on earnings before interest, taxes, depreciation, and amortization (EBITDA). Excess net interest may be carried forward indefinitely, and after 2009, unused EBITDA (from a year in which none of the exceptions from the limit are claimed) may be carried forward five years. A series of potential exceptions to the limitation may apply. Interest may be fully deducted provided that (1) total net interest does not exceed $€ 3$ million (about US\$3.8 million) per year; (2) the company is not a part of a consolidated group (and less than 10 percent interest expense is paid to a material shareholder); or (3) if the company is a member of a group, and its balance sheet total-to-equity ratio is no more than 2 percent less than the balance sheet total-to-equity ratio of the overall group as a whole (and less than 10 percent of net interest expense of each member of the group not eliminated in financial consolidation is paid to a material shareholder or an affiliate).

Germany has adopted tough exit tax rules for business restructurings (Kroppen, Roeder, and Schmidtke 2014). If certain conditions are satisfied related to the cross-border transfer of a business function from a German company that results in a reduction in the level at which the transferring company performs the function, then the pricing for the transfer must take account of the value of the risks and opportunities transferred.

The municipal trade tax is imposed on the federal corporate income tax base, adjusted with the addition back of some items and deduction of certain other items. For example, onefourth of most interest expense is added back, exempt dividend income from German corporations is added back, and a deduction is allowed for dividends from companies in which the German company owns at least 15 percent of the shares. The trade tax base generally does not

\footnotetext{
42 In addition to the general anti-avoidance rule, Germany has specific anti-avoidance rules. Starting in 2010, Germany requires extensive documentation of transactions with unrelated persons in uncooperative states or territories (generally, countries that do not engage in satisfactory exchange of information, regardless of whether they are party to a treaty with Germany). Germany also adopted specific domestic anti-treaty-shopping rules. These rules generally deny treaty dividend withholding relief and refund of dividend withholding tax on dividends to foreign companies to the extent that the foreign company itself does not have sufficient substance and cannot prove that its direct or indirect shareholders would be entitled to any withholding relief if they held the shares in the German corporation directly.
} 
include non-German income. The local tax rate is calculated by multiplying a municipal coefficient by a federally determined 3.5 percent base rate. The minimum multiple is 200 percent, so the minimum rate would be 7 percent, but municipalities on average use 400 percent for a rate of 14 percent.

\section{Summary}

Germany's public sector is large, and it raises substantial tax revenue in relation to GDP. The corporate tax is a relatively small 5 percent of its overall revenues. Moreover, as in the United States, pass-through entities earn a substantial portion of business income. Although Germany's combined federal and local taxes remain robust, Germany substantially reduced its corporate tax rate from 38 percent to 30 percent in 2008. This change was likely in response to tax competition within the EU. Other German tax law changes, including expanding the dividend exemption beyond treaty countries, have been necessary to respond to ECJ case law interpretations of EU law. In contrast to the United Kingdom, Germany has taken strict measures to protect its domestic tax base.

Although Germany is vocal in its opposition to corporate tax avoidance, its companies are probably practitioners of tax avoidance to the extent permitted (Bergin 2013). One of the authors of this report has heard a tax director of a major German multinational object that US companies are taxed much more favorably on their foreign income and that German companies are at a competitive disadvantage in relation to international taxation. US MNCs, of course, make the same claim in the opposite direction. Greater availability of data and more empirical research would be helpful.

\section{AUSTRALIA}

\section{Background}

Professor Miranda Stewart has characterized Australia's tax policy as pragmatic (cited in Toder 2014). As a small, open economy with substantial cross-border investment, Australia has had to accommodate to the policies of its major trading and investment partners. Historically, its main partners have been the United States and the United Kingdom, but today major trading partners also include China, Japan, and South Korea. The corporate tax is an important revenue source for Australia, and in relation to GDP (5.2 percent), it is more than twice as large as the corporate tax in the United States. Australia is the only one of the four countries reviewed in this report that still has an imputation system of taxation under which a credit for corporate tax is given at the shareholder level. Australia has had a form of territorial system for most of its history, except for 1987 to 1990 , when a foreign tax credit system was in effect. Since 2004, subject to certain conditions being satisfied, Australia has provided exemptions for both foreign dividends and foreign branch income. 


\section{Australian Corporate Taxation Today}

Residence and structure. A company is resident in Australia if it (1) is incorporated in Australia or (2) carries on business in Australia and either is managed and controlled in Australia or controlled by shareholders who are residents of Australia (Toryanik 2014). The corporate income tax rate is 30 percent. A dividend that has been subject to corporate-level tax is included in a resident shareholder's income. Under the Australian dividend imputation system, a "franked" dividend carries a credit for the corporate-level tax paid on profits underlying the dividend (the "franking credit") that may offset a resident shareholder's income tax.

Australia exempts from corporate tax non-portfolio dividends from foreign subsidiaries, income of a foreign branch from conducting an active business, and gains on the sale of nonportfolio stock in a foreign subsidiary conducting an active business. The un-franked profits represented by these categories of income do not carry with them a credit for foreign taxes and are taxable when distributed as a dividend to a resident shareholder (Taylor 2012). The top rate for a resident individual shareholder is 45 percent and increases to 49 percent when a Medicare levy and budget repair levy are taken into account. In effect, if foreign profits are earned by an Australian corporation and are distributed to a resident shareholder, they are fully taxed with no credit for foreign taxes, whether imposed at the corporate level or as a withholding tax (Miranda Stewart, cited in Toder 2014). Accordingly, foreign profits are relatively rarely distributed as a dividend by an Australian corporation with Australian resident shareholders.

In contrast to the taxation of a resident taxpayer on a distribution of an Australian corporation's foreign profits, under the conduit foreign income (CFI) regime, foreign profits distributed and declared as CFI are not subject to Australian withholding tax. Accordingly, a substantial difference exists in the taxation of a resident shareholder depending on whether the profits are distributed by the Australian corporation as a dividend or are retained. Under the CFI rules, a nonresident shareholder would not be affected by a distribution qualifying for $\mathrm{CFI}$ treatment.

CFC rules and other limitations on benefits of exemption. Australia has had CFC rules since 1990. Professor Stewart characterizes them as outdated and having a poor boundary between active and passive income. In comparison with other countries, however, Australia's CFC rules are closer to the historic US CFC rules than those of EU countries and Japan, and unlike the US CFC rules following adoption of check-the-box entity classification regulations, they remain effective.

A foreign company is a CFC if (1) five or fewer Australian entities (owning at least a 1 percent interest) and associates acquire a control interest of at least 50 percent in the company, (2) five or fewer Australian entities effectively control the company, or (3) one Australian entity owns a control interest of at least 40 percent in the company. Ownership may be direct or indirect. Income is attributable to an Australian entity that (with associates) owns directly or indirectly a 10 percent control interest. Generally, income of a CFC that satisfies an active 
income test will not be attributed to a shareholder. (Exceptions exist for categories of unconditionally attributed income.) Generally, the active income test is satisfied if tainted income is less than 5 percent of total turnover. Tainted income includes most passive income as well as income from sales of goods to or purchases from associates who are resident in Australia or carry on business in Australia and services provided to an associate or resident of Australia.

If a CFC is in a listed country with a comparable tax regime (Canada, France, Germany, Japan, New Zealand, the United Kingdom, and the United States) and fails the active income test, only certain "eligible designated concession income" will be attributed under the CFC rules. If the CFC is from an unlisted country (one other than a listed country), and does not satisfy the active income test, tainted income will be taxed. Australia uses a 3.0-to-1.0 debt-to-asset thin capitalization rule that soon will be reduced to a 1.5-to-1.0 limit. Generally, the maximum allowable debt is based on the average value of assets for the year, less associated and controlled foreign entity equity and debt and any non-debt liabilities (e.g., accruals). The maximum debt is 75 percent (soon to be reduced to 60 percent) of this amount or an amount that the taxpayer demonstrates could be borrowed from an arm's-length lender, based on a formal benchmarking analysis. Interest deductions are disallowed if the entity's adjusted average debt (reduced by average loans to associate entities and controlled foreign entities) exceeds its maximum allowable debt.

\section{Summary}

Australia relies on the corporate tax for almost 20 percent of its federal revenues. Its 30 percent corporate tax rate is relatively high, but it is mitigated by allowance of an imputation credit to domestic shareholders. The imputation credit system, however, undercuts the benefit of Australia's exemption of foreign profits if they are distributed to shareholders because they will then be subject to full shareholder taxation. Because no credit is given for foreign taxes at the corporate level and no franking credit at the shareholder level, foreign profits distributed to resident shareholders are, in essence, allowed only a deduction for foreign taxes. If the profits are retained at the corporate level, there is no further tax.

Australia differs from the United States in a number of dimensions. It is a substantially smaller economy and is a net importer of direct investment. It does not have a large pass-through sector and relies heavily on its corporate tax. Its tax rates are robust. Its imputation system of corporate taxation is increasingly unique and adversely affects untaxed foreign profits distributed by an Australian company to its resident shareholders. 
This section concludes by summarizing the basic findings from our research and discussions with experts.

\section{The United States is not practically bound to any international norm and can maintain different rules from other countries.}

Many examples of US tax exceptionalism exist: its definition of corporate residence, its checkthe-box rules, its taxation of repatriated dividends of US-based MNCs, and its taxation of the worldwide income of US individual income taxpayers on a citizenship instead of a residence basis. Although the United States tries to observe its treaty obligations, it historically has made tax law changes that differ from its treaty provisions, without being fundamentally offensive to them, and has modified treaties after the fact. Some potential policy changes, such as replacing foreign tax credits with deductions, would go further than in the past and could generate international responses at varying levels of severity. The same is less likely to be true for a move to territorial taxation by exempting repatriated dividends, because such a change would move toward other countries' practice. Expanding the scope of US taxation-for example, by further limiting deferral while maintaining a credit system to relieve double taxation-would move the United States away from other countries' practices (making US practices more exceptional) but would not violate any international norm.

As illustrated in section II, the US economy and the size and diversity of the US domestic market differ from what is found in other countries. The capacity of the United States to maintain international tax rules that differ to some degree from other countries clearly has been greater than that of other countries for reasons related to both its economy and the absence of constraints such as those that apply to EU member countries. Although there are costs of taking a different approach and little disagreement exists about the dysfunctional nature of the current rules, substantial disagreement remains about the direction of optimal changes and their relative benefits. The range of likely alternative approaches, however, does not appear to be limited by international norms or legal constraints.

\section{The classification of tax systems as worldwide or territorial oversimplifies and does not do justice to the variety of hybrid approaches taken in different countries.}

The differences between worldwide and territorial systems, in practice, when exceptions and anti-abuse rules are taken into account, are far less significant than the debate in the US tax policy community would suggest. The details of a system and the cultural context in which it is implemented are more important than which definitional category is applied to a particular system. One example is the former worldwide UK system under which companies could bring back foreign earnings through loans to related parties without such an arrangement being 
treated as a taxable repatriation. Another is the apparent absence of aggressive tax planning by Japanese companies.

\section{The circumstances that have caused other countries to maintain or introduce dividend exemption systems do not necessarily apply to the United States. Therefore, others' experiences do not necessarily dictate that the United States should follow the same path.}

The countries studied differed greatly in the extent to which they weighed conflicting policy concerns, such as effects on domestic investment, residence decisions of MNCs, tax avoidance through profit shifting, lock-in of overseas capital, and taxation of inbound investments. Countries also differed in their levels of concern about potential budgetary effects.

Other countries' decisions do not appear to have been based on analysis of how foreignsource income was effectively being taxed. In other words, the changes do not seem to have been driven by analysis of administrative data and seem, instead, to have been driven by anecdotal evidence to the extent that such decisions were even evidence based.

\section{The tax policies of other countries with territorial systems have been greatly influenced by their separate individual circumstances.}

Australia. As a net capital-importing country, Australia's main goal for its corporate tax has been to collect taxes from foreign corporate investors. It has less concern with treatment of outbound investment by Australian companies.

Australia has an imputation system, which allows domestic-but not foreign-shareholders to claim credits for domestic but not foreign corporate taxes paid by Australian companies. This system, in part, may reduce tax avoidance by Australian companies through shifting profits overseas, because Australian shareholders cannot get imputation credits if domestic corporate taxes have not been paid. Other countries, however, have repealed their imputation systems.

Germany. Germany adopted an exemption system many years ago to foster foreign investment by German companies. Other EU countries also had exemption systems, which influenced German practice.

German anti-avoidance rules appear to be more effective than most in limiting profit shifting by German-based companies, except to the extent that those rules are limited to conform to EU rules. Germany is, however, concerned about avoidance of German tax on inbound investment, which its CFC and other rules to limit tax avoidance by German-resident companies cannot combat. There is concern that this situation gives foreign companies a competitive advantage over domestic-based firms in the German market.

Japan. Japan adopted an exemption system in 2009 to make its companies more competitive and to encourage them to bring back accrued overseas profits to Japan. The tax culture in Japan is unique. Japanese firms do not appear to engage in aggressive tax-planning techniques. They do 
take advantage of explicit incentives, such as tax holidays offered by foreign countries, but do not engage in commonly used techniques to shift income to low-tax jurisdictions. One result of the unique Japanese tax culture is that its multinationals pay higher effective tax rates on their worldwide income than multinationals based elsewhere. One reason for Japan to go territorial and to begin to lower its corporate rate was to reverse this imbalance and make Japanese companies more competitive. Another result of this tax culture is that the Japanese government was not concerned that eliminating taxes on repatriated dividends would encourage more income-shifting and base-erosion behavior by Japanese MNCs. Japan did not enact any new antiavoidance rules to accompany the switch to a territorial system.

Japan also did not adopt a transition tax on repatriations from profits accrued before the effective date, possibly because it wanted to lower corporate tax burdens and to encourage its companies to bring back foreign profits, whether accrued before or after the change in the law. The Japanese also believed that exemption would be simpler to administer than the indirect foreign tax credit system

United Kingdom. The United Kingdom went to a territorial tax system in 2010 and lowered its top corporate tax rate to 21 percent. It also enacted patent box legislation that reduced the tax rate on intangible income to 10 percent. But the UK moves had much different motivations from those of the Japanese reforms.

The United Kingdom was mainly concerned with the movement of corporate headquarters out of the United Kingdom. Such moves were facilitated by a number of factors, including the proximity of the United Kingdom to other countries (Ireland, Luxembourg) with lower corporate tax rates and territorial systems and the absence of any anti-inversion rules in the United Kingdom (and EU restrictions against adopting such rules).

The United Kingdom was less concerned about tax avoidance by its multinationals, but concern has been raised in the United Kingdom that foreign-based multinationals, such as Starbucks, are shifting income out of the United Kingdom (Kleinbard 2013). The United Kingdom had close to the equivalent of an exemption system before the change because of rules that allowed corporations to return borrowed funds to their shareholders.

\section{Other countries find changing their tax laws much easier than the United States does and may be able to make corrections more easily if a provision has unintended effects.}

Japan has an annual process for review of its revenue laws. Other countries with parliamentary systems generally find enacting fiscal reforms much easier than the United States. The US system of divided responsibility between Congress and the executive branch often (as is the case now) leads to a division of power between the political parties. Intense and growing partisanship makes enacting complex fiscal reforms that produce large winners and losers even harder than usual for the United States. 
6. The fact that the United States has a lower ratio of corporate receipts to GDP than have other countries while having the highest statutory corporate income tax rate in the OECD has multiple explanations and does not necessarily suggest that US-based companies in any given industry are more aggressive at income shifting than foreign-based companies.

The United States has a larger share of its business income coming from pass-through entities that are not subject to corporate income tax than is the case in most other countries. (Germany also has a relatively large share of business income coming from pass-through entities and a relatively low level of corporate receipts as a percentage of GDP.) At the same time, the United States has relatively large high-tech and pharmaceutical sectors. Companies in these sectors are the ones mostly likely to have a large share of their capital in the form of intangible assets that are easy to shift to entities in low-tax jurisdictions. Although evidence exists of income shifting by US companies (Grubert 2013), comparable data on companies from other countries are insufficient to conclude that US companies are more or less aggressive than their peer competitors from other countries.

7. The burden of repatriation taxes may be a lot higher in the United States than it was in the United Kingdom and Japan before they adopted dividend exemption systems.

As discussed in section III, Grubert and Altshuler (2013) estimate that the burden on US companies of retaining profits overseas to avoid the repatriation tax at about 7 percent of foreign-source income. For reasons particular to each country, this burden did not appear to be a major factor in the decision to shift to a territorial tax system in the United Kingdom or Japan. Hence, those countries' decisions offer relatively little direct guidance for resolving the disagreement in the United States over the optimal approach to reducing this burden.

8. Studies based on US tax data have provided statistical as well as anecdotal evidence that suggests that US multinationals are avoiding corporate income tax by shifting reported income to low-tax jurisdictions (Grubert 2013). Other countries do not collect or report publicly as much data, so we do not have as much statistical evidence regarding profit shifting by foreign-based multinationals.

Anecdotal evidence suggests that foreign-based multinationals may be engaging in similar transactions and perhaps even to a greater degree. Complaints from overseas that focus on the behavior of certain large US multinationals may in part be driven by the fact that more data are available on the behavior of US multinationals than on that of non-US multinationals. A major part of the OECD Base Erosion and Profit Shifting Project will be to compile new data on the behavior of MNCs to help understand the degree of income shifting and where it is occurring.

\section{The global tax environment has changed greatly.}

In the past two decades, the differences between the United States and other countries have widened. The United States is now the only major country that taxes most foreign-source income of its resident corporations, even though it mainly imposes the tax only when the income is 
repatriated. But the United States has become more different in other ways that may be even more important. The United States is the only country that does not use a national sales tax to raise revenues; in the past few decades, many countries, including Canada, Australia, and Japan, have introduced a VAT. Corporate statutory rates around the world have fallen, but the US. corporate rate has stayed the same since 1993. The share of business income in the United States that is taxed at the corporate level has been declining since the 1980s and today is less than 40 percent, while in most other countries, business income is typically subject to corporate income tax. Emerging economies have acquired importance in international tax policy discussions and generally have adopted the perspective of a host country seeking to attract inbound investment. Accumulating evidence that multinational corporations are shifting more of their reported income to countries with very low taxes is driving discussion of reforms in the United States and other countries. An important development is the OECD Base Erosion and Profit Shifting Project, under which countries are starting to discuss coordinated action to combat the use of tax havens.

\section{The United States is subject to many of the same pressures facing other countries that have lowered corporate tax rates and have eliminated taxation of repatriated dividends.}

As an investment location, the United States faces growing competition from jurisdictions with lower corporate tax rates. US-based multinationals face growing competition from multinationals based in countries with exemption systems. But no country has a pure territorial system, and CFC rules and other antiavoidance rules matter, so the claimed disadvantage that US multinationals face may be exaggerated (Kleinbard 2014). At least on the surface, however, other countries' CFC rules do not appear to be more robust than US rules (Arnold 2012).

The advantages of foreign residence have increased incentives for some US-based firms to re-domicile as foreign-based firms. The rising costs of repatriations as US firms accumulate more cash overseas and as foreign corporate income tax rates decline, combined with the ability of expatriated firms to circumvent taxes that would otherwise be payable on repatriations from accrued assets in US CFCs (Kleinbard 2014), puts increased pressure on firms to consider giving up US residence. And foreign residence makes it easier for corporations to strip income out of the United States through earnings-stripping techniques involving interest and royalties (Shay 2014), a problem that would persist under a dividend exemption system if the United States retained its $\mathrm{CFC}$ rules.

\section{The United States has been more able than other countries to maintain some taxation based on corporate residence and higher corporate tax rates.}

The US market is large and important enough and has enough unique productive resources that companies will invest there (albeit somewhat less) even if US corporate rates are higher than elsewhere. The United States has some of the world's leading multinationals with unique assets in certain areas (e.g., high-tech, finance, and retailing). The current level of activity with respect to inversions indicates increasing pressure on the US corporate tax rules. Although the ultimate 
policy response to inversions is hard to predict, the most plausible outcomes likely will retain material differences between the US tax system and those of other countries.

12. As the economic differences between the United States and other countries narrow, however, and the US share of world output declines, the ability of the United States to sustain US tax exceptionalism will also decline.

These factors will make it harder over time for the United States to maintain a corporate tax rate that is higher than those of other major economies and to sustain tougher rules for taxing foreign-source income of resident multinationals. The recent wave of inversions is evidence of the ability of MNCs to establish corporate residence outside the United States and their interest in doing so.

13. As competition among countries for corporate residence and corporate investment intensifies and multinationals continue to shift reported income to tax havens, additional international cooperation will be needed to prevent erosion of the corporate tax base in both the OECD and emerging economies.

The OECD Base Erosion and Profit Shifting Project, undertaken at the request of the Group of 20 , is evidence of an increasing international awareness of the need for international cooperation in protecting the corporate tax base. Although more hard data on income-shifting behavior are available for US-based MNCs than for MNCs based elsewhere, many reasons exist to suspect that many foreign-based multinationals are exploiting the same or similar avoidance techniques. 
TABLES

Table 1. Comparison of Population, GDP, and Dependence on Foreign Trade, 2012

\begin{tabular}{|c|c|c|c|c|c|}
\hline $\begin{array}{l}\text { GDP, population, } \\
\text { exports, imports }\end{array}$ & Australia & Germany & Japan & $\begin{array}{l}\text { United } \\
\text { Kingdom }\end{array}$ & $\begin{array}{l}\text { United } \\
\text { States }\end{array}$ \\
\hline GDP (billions of US\$) & $1,027.1$ & $3,434.2$ & $4,525.8$ & $2,259.7$ & $16,244.6$ \\
\hline Population (millions) & 22.7 & 81.9 & 127.5 & 63.7 & 313.9 \\
\hline GDP per capita (US\$) & 45,197 & 41,915 & 35,492 & 35,471 & 51,749 \\
\hline $\begin{array}{l}\text { Exports of goods and services (\% of } \\
\text { GDP) }\end{array}$ & 19.8 & 51.8 & 14.7 & 31.8 & 12.9 \\
\hline $\begin{array}{l}\text { Imports of goods and services (\% of } \\
\text { GDP) }\end{array}$ & 21.0 & 45.9 & 15.5 & 33.9 & 16.4 \\
\hline
\end{tabular}

Sources: OECD StatExtracts GDP database, http://stats.oecd.org/index.aspx?queryid=9185; OECD StatExtracts database on OECD-WTO Trade in Value Added (TiVA), http://stats.oecd.org/Index.aspx?DataSetCode=TIVA OECD WTO. 
Table 2. Comparison of Capital Positions as Shares of GDP, 2012

\begin{tabular}{|c|c|c|c|c|c|}
\hline $\begin{array}{l}\text { Capital positions as a } \\
\text { share of GDP }\end{array}$ & Australia & Germany & Japan & $\begin{array}{l}\text { United } \\
\text { Kingdom }\end{array}$ & $\begin{array}{l}\text { United } \\
\text { States }\end{array}$ \\
\hline Inbound FDI (\%) & 36.1 & 26.1 & 3.8 & 60.1 & 16.3 \\
\hline Outbound FDI (\%) & 24.4 & 36.5 & 19.0 & 69.8 & 27.4 \\
\hline Inbound portfolio investment (\%) & 102.2 & 89.1 & 31.6 & 163.7 & 55.3 \\
\hline Outbound portfolio investment (\%) & 51.2 & 69.3 & 77.9 & 157.2 & 48.7 \\
\hline Net outbound FDI (\%) & -11.8 & 10.4 & 15.2 & 9.7 & 11.1 \\
\hline $\begin{array}{l}\text { Net outbound portfolio investment } \\
\text { (\%) }\end{array}$ & -51.0 & -19.8 & 46.3 & -6.6 & -6.6 \\
\hline
\end{tabular}

Sources: Inward and outbound FDI from OECD Factbook 2014, Outward and inward FDI stocks table, OECD ilibrary, http://www.oecd-ilibrary.org/economics/oecd-factbook-2014/outward-and-inward-fdistocks factbook-2014-table77-en; portfolio investment from International Monetary Fund, Coordinated Portfolio Investment Survey (CPIS), http://elibrary-

data.imf.org/DataReport.aspx?c=26593551\&d=33061\&e=169309. 
Table 2a. Comparison of Capital Positions as Shares of GDP, 2011

\begin{tabular}{|c|c|c|c|c|c|}
\hline $\begin{array}{l}\text { Capital positions as share } \\
\text { of GDP }\end{array}$ & Australia & Germany & Japan & $\begin{array}{l}\text { United } \\
\text { Kingdom }\end{array}$ & $\begin{array}{l}\text { United } \\
\text { States }\end{array}$ \\
\hline Inbound FDI (\%) & 34.1 & 26.2 & 3.7 & 51.6 & 16.1 \\
\hline Outbound FDI (\%) & 22.5 & 34.5 & 15.8 & 71.1 & 28.7 \\
\hline Inbound portfolio investment (\%) & 99.7 & 80.7 & 31.0 & 156.3 & 54.8 \\
\hline Outbound portfolio investment (\%) & 49.6 & 68.7 & 77.0 & 145.8 & 43.9 \\
\hline Net outbound FDI (\%) & -11.5 & 8.3 & 12.1 & 19.5 & 12.6 \\
\hline Net outbound portfolio investment (\%) & -50.1 & -12.0 & 46.0 & -10.5 & -10.9 \\
\hline
\end{tabular}

Sources: Inward and outbound FDI from OECD Factbook 2014, Outward and inward FDI stocks table, OECD ilibrary, http://www.oecd-ilibrary.org/economics/oecd-factbook-2014/outward-and-inward-fdistocks factbook-2014-table77-en; portfolio investment from International Monetary Fund, CPIS, http://elibrary-data.imf.org/DataReport.aspx?c=26593551\&d=33061\&e=169309. 
Table 2b. Comparison of Capital Positions as Shares of GDP, 2010

\begin{tabular}{|c|c|c|c|c|c|}
\hline $\begin{array}{l}\text { Capital positions as } \\
\text { share of GDP }\end{array}$ & Australia & Germany & Japan & $\begin{array}{l}\text { United } \\
\text { Kingdom }\end{array}$ & $\begin{array}{l}\text { United } \\
\text { States }\end{array}$ \\
\hline Inbound FDI (\%) & 33.6 & 26.5 & 3.6 & 48.8 & 15.2 \\
\hline Outbound FDI (\%) & 26.6 & 33.6 & 14.0 & 70.4 & 29.8 \\
\hline Inbound portfolio investment (\%) & 101.7 & 90.1 & 30.9 & 165.4 & 56.2 \\
\hline Outbound portfolio investment (\%) & 51.1 & 79.0 & 77.4 & 150.8 & 45.0 \\
\hline Net outbound FDI (\%) & -7.0 & 7.1 & 10.4 & 21.6 & 14.5 \\
\hline $\begin{array}{l}\text { Net outbound portfolio investment } \\
\text { (\%) }\end{array}$ & -50.6 & -11.1 & 46.5 & -14.6 & -11.2 \\
\hline
\end{tabular}

Sources: Inward and outbound FDI from OECD Factbook 2014, Outward and inward FDI stocks table, OECD ilibrary, http://www.oecd-ilibrary.org/economics/oecd-factbook-2014/outward-and-inward-fdistocks factbook-2014-table77-en; portfolio investment from International Monetary Fund, CPIS, http://elibrary-data.imf.org/DataReport.aspx?c=26593551\&d=33061\&e=169309. 
Table 2c. Comparison of Capital Positions as Shares of GDP, 2000 (2001)-2012

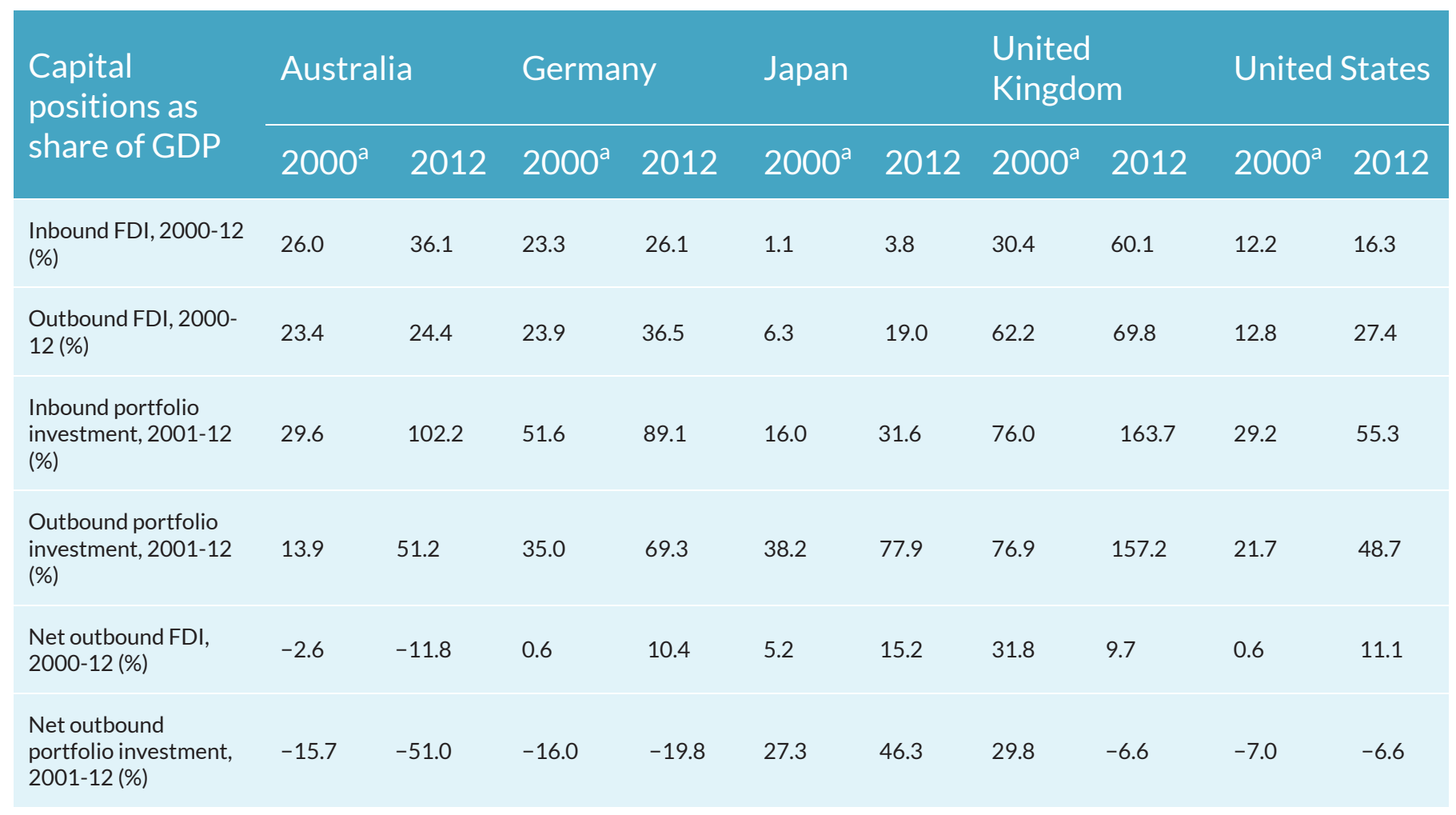

Sources: Inward and outbound FDI from OECD Factbook 2014, Outward and inward FDI stocks table, OECD ilibrary, http://www.oecd-ilibrary.org/economics/oecd-factbook-2014/outward-and-inward-fdistocks factbook-2014-table77-en; portfolio investment from International Monetary Fund, CPIS, http://elibrary-data.imf.org/DataReport.aspx?c=26593551\&d=33061\&e=169309.

a. Portfolio investment figures are for 2001. 
Table 3. Comparison of Distribution of Value Added by Economic Sector

\begin{tabular}{|c|c|c|c|c|c|}
\hline Share of value added & Australia & Germany & Japan & $\begin{array}{l}\text { United } \\
\text { Kingdom }\end{array}$ & $\begin{array}{l}\text { United } \\
\text { States }^{a}\end{array}$ \\
\hline Agriculture, forestry, and fishing (\%) & 2.4 & 0.8 & 1.2 & 0.7 & 0.9 \\
\hline $\begin{array}{l}\text { Industry, including energy and excluding } \\
\text { manufacturing (\%) }\end{array}$ & 11.7 & 3.5 & 1.8 & 4.6 & 3.9 \\
\hline Manufacturing (\%) & 7.1 & 22.4 & 18.2 & 10.1 & 9.7 \\
\hline Construction (\%) & 8.3 & 4.7 & 5.7 & 6.0 & 4.0 \\
\hline $\begin{array}{l}\text { Distributive trade, repairs, transport, accommodations, } \\
\text { and food service (\%) }\end{array}$ & 16.8 & 14.6 & 19.5 & 18.2 & 16.5 \\
\hline Information and communication (\%) & 3.0 & 4.0 & 5.6 & 6.6 & 7.4 \\
\hline Financial and insurance activities (\%) & 8.7 & 4.0 & 4.6 & 8.0 & 8.2 \\
\hline Real estate activities (\%) & 11.6 & 12.1 & 12.1 & 11.0 & 9.6 \\
\hline $\begin{array}{l}\text { Professional, scientific, technical, administrative, and } \\
\text { other service activities (\%) }\end{array}$ & 13.1 & 15.6 & 19.9 & 15.6 & 16.1 \\
\hline $\begin{array}{l}\text { Public administration, compulsory social security, } \\
\text { education, and human health (\%) }\end{array}$ & 17.4 & 18.4 & 11.6 & 19.4 & 23.7 \\
\hline
\end{tabular}

Source: OECD StatExtracts GDP database, http://stats.oecd.org/Index.aspx?.DatasetCode=SNA TABLE1.

a. Data were unavailable for the United States. Figures are calculated by assuming that the United States has the same ratio of value added to compensation in each sector as the unweighted average of the ratios for Australia, Germany, Japan, and the United Kingdom. 
Table 4. Receipts, Expenditures, Deficits, and Net Debt, 2012

\begin{tabular}{|lccccc|}
$\begin{array}{l}\text { Budget measures } \\
\text { as share of GDP }\end{array}$ & Australia & Germany & Japan & $\begin{array}{l}\text { United } \\
\text { Kingdom }\end{array}$ & $\begin{array}{l}\text { United } \\
\text { States }\end{array}$ \\
\hline Revenue (\%) & 33.1 & 44.8 & 31.2 & 36.8 & 29.0 \\
\hline Spending (\%) & 36.8 & 44.7 & 39.9 & 44.8 & 38.7 \\
\hline Public deficit (\%) & 3.7 & -0.1 & 8.7 & 8.0 & 9.7 \\
\hline Net government debt (\%) & 11.3 & 58.2 & 129.5 & 81.4 & 80.1 \\
\hline
\end{tabular}

Source: IMF Fiscal Monitor: Public Expenditure Reform: Making Difficult Choices. (2014). Methodological and Statistical Appendix, tables 3 and 4. 
Table 5. Share of Tax Receipts by Source, 2011

\begin{tabular}{|c|c|c|c|c|c|}
\hline $\begin{array}{l}\text { Share of tax } \\
\text { receipts }\end{array}$ & Australia & Germany & Japan & $\begin{array}{l}\text { United } \\
\text { Kingdom }\end{array}$ & $\begin{array}{l}\text { United } \\
\text { States }\end{array}$ \\
\hline Personal income taxes (\%) & 39.3 & 24.8 & 18.4 & 28.2 & 37.1 \\
\hline Corporate income taxes (\%) & 19.7 & 4.7 & 11.8 & 8.6 & 9.4 \\
\hline $\begin{array}{l}\text { Social security and payroll } \\
\text { taxes (\%) }\end{array}$ & 5.2 & 38.5 & 41.4 & 18.7 & 22.8 \\
\hline Property taxes ${ }^{\mathrm{a}}(\%)$ & 8.6 & 2.4 & 9.7 & 11.6 & 12.4 \\
\hline Goods and services taxes (\%) & 27.1 & 29.1 & 18.4 & 32.3 & 18.3 \\
\hline Other (\%) & 0.1 & 0.5 & 0.3 & 0.6 & $-b$ \\
\hline
\end{tabular}

Source: OECD Tax Policy Analysis, Revenue Statistics Tax Structures, table 6, http://www.oecd.org/ctp/tax-policy/revenue-statistics-tax-structures.htm.

Note: Figures in table include receipts of both national and subnational governments.

a. Includes estate and gift taxes.

b. Less than 0.05 percent. 
Table 6. Comparison of Corporate Tax Rates (2014) and Receipts (2011)

\begin{tabular}{|llcccc|}
$\begin{array}{l}\text { Corporate tax } \\
\text { comparisons }\end{array}$ & Australia & Germany & Japan & $\begin{array}{l}\text { United } \\
\text { Kingdom }\end{array}$ & $\begin{array}{l}\text { United } \\
\text { States }\end{array}$ \\
\hline Corporate tax rate (\%) & 30.0 & 30.2 & 37.0 & 21.0 & 39.1 \\
\hline National (\%) & 30.0 & 15.8 & 28.1 & 21.0 & 35.0 \\
\hline State and local (\%) & 0.0 & 14.4 & 10.8 & 0.0 & 6.3 \\
\hline Corporate receipts (\% of GDP) & 5.2 & 1.7 & 3.4 & 3.1 & $2.3^{\mathrm{a}}$ \\
\hline
\end{tabular}

Note: National and state and local rates may add up to more than total if part or all of local rate is deductible in computing the national tax.

Source: OECD, Tax Policy Analysis, OECD Tax Database, historical table II.1, http://www.oecd.org/tax/tax-policy/tax-database.htm\#C CorporateCaptial.

a. The OECD figures are based on the US National Income Accounts and include Federal Reserve Bank profits in corporate taxes. Excluding Federal Reserve profits, the US corporate tax share of GDP would be slightly lower. 
Table 7. Comparison of Tax Rates on Corporate Equity Income, 2014

\begin{tabular}{|lccccc|}
\hline Maximum tax rate & Australia & Germany & Japan & $\begin{array}{c}\text { United } \\
\text { Kingdom }\end{array}$ & $\begin{array}{c}\text { United } \\
\text { States }\end{array}$ \\
\hline Corporate tax rate (\%) & 30.0 & 30.2 & 37.0 & 21.0 & 39.1 \\
\hline Personal tax rate on dividends (\%) & $49.0^{\mathrm{a}}$ & 26.4 & 20.3 & 37.5 & 30.3 \\
\hline Net personal tax rate on dividends ${ }^{\mathrm{b}}(\%)$ & 19.0 & 18.4 & 12.8 & 24.1 & 18.5 \\
\hline Combined personal and dividend rates (\%) & 49.0 & 48.6 & 49.8 & 45.1 & 57.6 \\
\hline Share of rate from corporate tax (\%) & 64.5 & 62.1 & 74.3 & 46.5 & 67.9
\end{tabular}

Source: OECD, Tax policy analysis, OECD Tax Database, historical table II.1, http://www.oecd.org/tax/tax-policy/tax-database.htm\#C CorporateCaptial.

Note: Table shows combined rates of both national and subnational governments.

a. Includes 45.0 percent maximum personal tax rate plus 2.0 percent Medicare levy and 2.0 percent temporary budget repair levy.

b. Net of deductibility from corporate income tax and imputation credits. 
Table 8. Comparison of Types of Businesses

\begin{tabular}{|c|c|c|c|c|c|}
\hline & $\begin{array}{l}\text { Australia, } \\
2010 / 11\end{array}$ & $\begin{array}{l}\text { Germany, } \\
2007\end{array}$ & $\begin{array}{l}\text { Japan, } \\
2011\end{array}$ & $\begin{array}{l}\text { United } \\
\text { Kingdom, } \\
2010 / 11\end{array}$ & $\begin{array}{l}\text { United } \\
\text { States, } \\
2008\end{array}$ \\
\hline $\begin{array}{l}\text { Share of businesses subject to corporate } \\
\text { income tax (\%) }\end{array}$ & 5.3 & 28.7 & 41.3 & 16.2 & 5.6 \\
\hline $\begin{array}{l}\text { Share of business profits subject to } \\
\text { corporate income tax (\%) }\end{array}$ & 81.9 & 45.3 & 86.7 & 79.8 & 34.4 \\
\hline
\end{tabular}

Sources:

Australia: Australian Taxation Office, Taxation Statistics, 2010-11, https://www.ato.gov.au/AboutATO/Research-and-statistics/Previous-years/Tax-statistics/Taxation-statistics-2010-11/. Germany: DEStatis Statistiches Bundesamt, Corporation Tax, https://www.destatis.de/EN/FactsFigures/SocietyState/PublicFinanceTaxes/Taxes/Taxes.html. Japan: Statistics Japan, Japan Statistical Yearbook, table 6-7, http://www.stat.go.jp/english/data/nenkan/143106.htm. United Kingdom: Her Majesty's Revenue and Customs (HRMC), Statistics at HMRC, https://www.gov.uk/government/organisations/hm-revenue-customs/about/statistics. United States:IRS, Statistics of Income (SOI), SOI Tax Stats: Integrated Business Data, table 1, http://www.irs.gov/uac/SOITax-Stats-Integrated-Business-Data.

a. Businesses include sole proprietorships and self-employed taxpayers. 
Altshuler, Rosanne, Benjamin H. Harris, and Eric Toder. 2010. "Capital Income Taxation and Progressivity in a Global Economy.” Virginia Tax Review 30 (2): 355-88.

Arnold, Brian J. 2012. "A Comparative Perspective on the US Controlled Foreign Corporation Rules." Tax Law Review 65 (3): 473-505.

Bergin, Tom. 2013. "Special Report: How a German Tech Giant Trims Its US Tax Bill." Reuters, September 20.

Boos, Peter. 2014. "Runaway REIT Train? Impact of Recent IRS Rulings." Tax Notes, September 15.

Committee on Finance, US Senate. 2013. "Baucus Unveils Proposals for International Tax Reform." Press release, November 19. http://www.finance.senate.gov/newsroom/chairman/release/?id=f946a9f3-d296-42ad-bae4bcf451b34b14.

Committee on Ways and Means, US House of Representatives. 2014. "Camp Releases Tax Reform Plan to Strengthen the Economy and Make the Tax Code Simpler, Fairer, and Flatter." Press release, February 26. http://waysandmeans.house.gov/news/documentsingle.aspx?DocumentID=370987.

Fleming, J. Clifton Jr., Robert J. Peroni, and Stephen E. Shay. Forthcoming. "Formulary Apportionment in the US International Income Tax System: Putting Lipstick on a Pig?" Michigan Journal of International Law 36: 101-60.

Galizia, Matthew Caruana, Mar Cabra, Margot Williams, Emilia Díaz-Struck, and Hamish Boland Rudder. 2014. "Explore the Documents: Luxembourg Leaks Database." International Consortium of Investigative Journalists, December 9. http://www.icij.org/project/luxembourg-leaks/exploredocuments-luxembourg-leaks-database.

Grubert, Harry. 2013. "Foreign Taxes and the Growing Share of US Multinational Company Income Abroad: Profits, Not Sales Are Being Globalized." National Tax Journal 65 (2): 247-81.

Grubert, Harry, and Rosanne Altshuler. 2013. "Fixing the System: An Analysis of Proposals for Reform of International Taxation." National Tax Journal 66 (3): 671-712.

Halperin, Daniel I. 2009. Mitigating the Potential Inequity of Reducing Corporate Rates. Tax Policy Center Working Paper, July 29. Washington, DC: Urban Institute and Brookings Institution. 
Halperin, Daniel I., and Alvin C. Warren Jr. 2014. "Understanding Income Tax Deferral." Tax Law Review 67 (3): 317-34.

Hartman, David. 1985. "Tax Policy and Foreign Direct Investment." Journal of Public Economics 26 (1): 107-21.

Hassett, Kevin A., and Aparna Mathur. 2011. "Report Card on Effective Corporate Tax Rates: United States Gets an F." Tax Policy Outlook 1 (February). Washington, DC: American Enterprise Institute.

Kleinbard, Edward D. 2013. "Through a Latte Darkly: Starbucks' Stateless Income Planning." Tax Notes, June 24.

---. 2014. "Competitiveness Has Nothing to Do with It." Tax Notes, September 1.

Kroppen, Heinz-Klaus, Achim Roeder, and Richard Schmidtke. 2014. International Bureau of Fiscal Documentation Tax Research Platform, Topical Analyses, Transfer Pricing and Business Restructuring. "Germany." http://www.ibfd.org/IBFD-Tax-Portal/Topical-Analyses.

Marples, Donald J., and Jane G. Gravelle. 2014. Corporate Expatriation, Inversions, and Mergers: Tax Issues. CRS Report to Congress R43568. Washington, DC: Congressional Research Service.

Masui, Yoshihiro. 2010. “Taxation of Foreign Subsidiaries: Japan's Tax Reform 2009/10." Bulletin for International Taxation 64 (4): 242-48.

Perdelwitz, Andreas. 2014. Germany: Corporate Taxation. Country Analysis. Amsterdam: International Bureau of Fiscal Documentation. Sections 1.1.1 and 1.1.3.

Shay, Stephen E. 2014. "Mr. Secretary, Take the Tax Juice out of Corporate Expatriations." Tax Notes, July 28.

Shay, Stephen E., J. Clifton Fleming Jr., and Robert J. Peroni. 2013. "Territoriality in Search of Principles and Revenue: Camp and Enzi." Tax Notes Special Reports, October 14: 155-90.

Sieker, Klaus. 2014. Business Operations in Germany. Amsterdam: International Bureau of Fiscal Documentation. V.B.4.b(5) and V.B.2.d(2)(c).

Taylor, C. John. 2012. "Australia." In Taxation of Intercompany Dividends under Tax Treaties and EU Law, edited by Guglielmo Maisto (203-78). EC and International Tax Law Series, Vol. 8. Amsterdam: International Bureau of Fiscal Documentation.

Toder, Eric. 2014. Review of Conference on What the United States Can Learn from the Experience of Countries with Territorial Systems. Washington, DC: Urban Institute and Brookings Institution. 
Toryanik, Tom. 2014. Australia: Individual Taxation. Country Analysis. Amsterdam: International Bureau of Fiscal Documentation. Section 1.10.1.

US Office of Management and Budget. 2014. Analytical Perspectives: Budget of the United States Government, Fiscal Year 2015. Washington, DC: US Government Printing Office.

Valcke, Catherine. 2004. "Comparative Law as Comparative Jurisprudence: The Comparability of Legal Systems." American Journal of Comparative Law 52: 713-40.

Warren, Alvin C. Jr. 2014. Deferral and Exemption of the Income of Foreign Subsidiaries: A Review of the Basic Analytics. Harvard Public Law Working Paper 14-18. Cambridge, MA: Harvard Law School. 


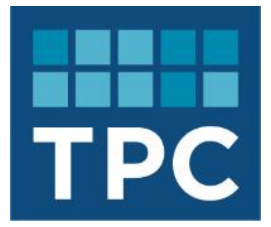

The Tax Policy Center is a joint venture of the Urban Institute and Brookings Institution.

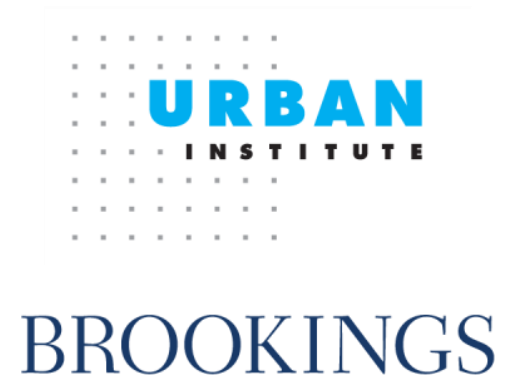

For more information, visit taxpolicycenter.org oremailinfo@taxpolicycenter.org 